\title{
On the Relationship of Metachromatic Leucodystrophy and Amaurotic Idiocy
}

BY

MIROSLAW MOSSAKOWSKI, GORDON MATHIFSON and JOHN N. CUMINGS

[Reprinted from Brain, Vol. 84, Part IV, 1961, pp. 585-604]

MACMILLAN AND CO., LIMITED

ST. MARTIN'S STREET, LONDON

ST. MARTIN'S PRESS, INC.

175 FIFTH AVENUE, NEW YORK IO, N.Y. I96I 


\section{ON THE RELATIONSHIP OF METACHROMATIC LEUCODYSTROPHY AND AMAUROTIC IDIOCY}

BY

\section{MIROSLAW MOSSAKOWSKI, ${ }^{1}$ GORDON MATHIESON AND JOHN N. CUMINGS}

(From the Department of Neurology and Neurosurgery, McGill University and Montreal Neurological Institute, and from the Department of Chemical Pathology, Institute of Neurology, the National Hospital, Queen Square, London)

THE existence of a close and pathogenetically significant relationship between amaurotic family idiocy and metachromatic leucodystrophy has frequently been suggested on both morbid anatomical and biochemical grounds. Two morphological observations support this hypothesis: first, the occurrence of lipid storage within the cytoplasm of neurones of certain fairly constant nuclear groups in cases of metachromatic leucodystrophy (Wicke, 1938; Norman, 1947; Brain and Greenfield, 1950; Greenfield, 1950; Leslie, 1952; Peiffer and Hirsch, 1955; Jervis, 1958, 1960; and others) and secondly the presence in some cases of amaurotic family idiocy of large areas deficient in myelin but containing, in addition to neutral fats, substances called prelipids (Ostertag, 1925; Bérard-Badier, et al., 1958). From a biochemical viewpoint, an increase in the hexosamine and neuraminic acid content of the brain has been found in both conditions; in metachromatic leucodystrophy this increase is in the white matter (Edgar, 1955 $a$ and $b$ ) while in amaurotic idiocy it has been observed in samples of grey matter (Cumings, 1953).

The object of this paper is to describe the pathological findings in 3 siblings who exemplify this association in remarkable degree and to discuss the results of histochemical and biochemical studies.

The 3 sibs who form the subject of the present report come from a sibship of 5 in a French-Canadian family (fig. 1). The parents are young, healthy and not consanguineous. There was no neurological disease in the parents' or grandparents' generations. The two youngest siblings in this family, twins born in 1957, are developing normally, and examination at the age of 3 years did not reveal any abnormality suggestive of the disease which involved the older siblings.

${ }^{1}$ Fellow of the Polish Academy of Sciences, Warsaw, Poland. 


\section{Clinical Histories}

Case 1.-The oldest child, a boy André, was delivered normally following a full term, normal pregnancy. His development was slightly retarded from birth. He sat up at 8 months, stood with support at the age of 1 year but never walked independently. At the age of 2 years, he began to have episodes in which his eyes turned upwards, and during which he was unresponsive. At the same age he began to utter high-pitched cries. At about this time he had chickenpox and thereafter rapid mental and physical deterioration ensued; he stopped speaking and lost the ability to stand or sit upright. At the age of $2 \frac{1}{2}$ years he was admitted to the Montreal Neurological Institute. He was small, poorly developed, and poorly nourished. He lay quietly in bed without reaction

\section{FAMILY TREE}

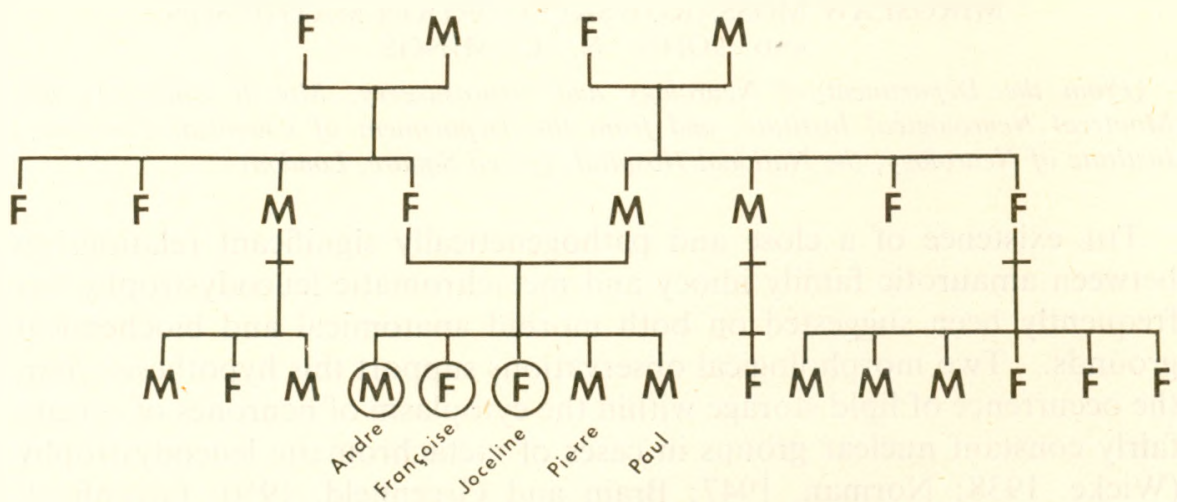

FIG. 1.-Family tree showing relationship of cases.

to his surroundings except for a high pitched cry when moved. The head was small, measuring $46 \mathrm{~cm}$. in circumference. He did not follow objects with his eyes; he appeared to be blind. The pupils did not react to light but did react on occasions of spontaneous convergence. There was bilateral convergent strabismus. The optic fundi were normal; in particular there was no optic atrophy or abnormal retinal pigmentation. The child appeared to be deaf. The arms and legs were very spastic but some spontaneous movements were present. Tendon reflexes in the arms were very weak; the knee-jerks were brisk and the ankle-jerks doubtfully present. The plantar responses were extensor. Examination of chest and abdomen was non-contributory. Hæmogram, urinalysis and serological tests for syphilis gave normal results. Cerebrospinal fluid protein was $29 \mathrm{mg}$. per cent; no cells were present. An EEG showed severe diffuse abnormality. X-rays of the skull showed widening of the coronal suture. A ventriculogram showed great dilatation of lateral and third ventricles; the cerebral aqueduct was not visualized and was therefore considered to be obstructed. Because of this a ventriculo-cisternostomy was carried out and a biopsy specimen of brain obtained. His subsequent course was one of progressive deterioration and he died at home early in 1955 at just under 3 years of age. Unfortunately post-mortem examination was not obtained.

Case 2.-Françoise, the second child in the family, was two years younger than her brother André. Her delivery and early development were entirely normal. At the age of 14 months her parents noticed an arrest of her development and later a deterioration of her mental and physical status. At the beginning of her illness, she developed 
difficulty in walking with a tendency to fall backwards. Later her sight gradually deteriorated. Gradual impairment of hearing ensued. She stopped walking and speaking, and eventually did not react to visual or acoustic stimuli. At no time was any abnormality observed in the ocular fundi. The illness was very slowly progressive. She died at the age of 5 years in a marasmic state. Full post-mortem examination was carried out.

Case 3.- Joceline was the third child in the family. She was $2 \frac{1}{2}$ years younger than her sister, Françoise. Like her sister, she developed normally until the fifteenth month of her life; from then onwards she developed an almost identical illness. There was impairment of walking and arrest and later deterioration of her mental ability. She developed profound dementia, spasticity of all limbs and extreme marasmus. There was no significant abnormality of the ocular fundi. The course of her illness was more rapid than in Françoise's case, and she died at the age of three years, twenty months after the onset of her illness. Full post-mortem examination was carried out.

\section{Pathological Observations}

Case 1.--In this case, only diagnostic brain biopsy was carried out. The biopsy material comprised cortex and white matter from the right parietal lobe. There was loss of normal cyto-architectural pattern in the cortex, only the molecular and the external granular layers being clearly identifiable. There was also a slight generalised loss of neurones. The majority of cortical neurones showed globular distension of their cell bodies. Their nuclei were displaced to the periphery, mainly towards the apical dendrites. Nissl granules were extremely scanty and the neuronal cytoplasm, when stained with ordinary chromatic dyes, had a pale, slightly reticulated or finely granular appearance. These granules were strongly positive when stained by the periodic acid Schiff reagent and with Sudan Black B. They were pale yellowishorange in Sudan IV-stained, paraffin-processed sections. There was remarkable proliferation of glial cells, both astrocytes and microglia, within the cortex. In the white matter there was moderate pallor of myelin sheaths in Heidenhain's stain. This was accompanied by glial proliferation with hypertrophied astrocytes. The white matter and, to a much lesser degree, the cortex contained phagocytes filled with coarse granular material. This material was strongly positive in PAS preparations, pale grey in Sudan Black B, and entirely negative in Sudan IV. The cytoplasm of these phagocytes was not seen in cresyl violet-stained, paraffin sections. Preparations to demonstrate metachromasia were not made at the time of initial investigation and, as all the remaining material was embedded in paraffin, this property could not be assessed subsequently. Apart from these intracellular granular accumulations, there were some loose masses of granular material scattered throughout the tissue. Very slight perivascular lymphocytic infiltration was present.

Case 2.-At post-mortem examination, carried out about fifteen hours after death, the body was emaciated and there was generalized brown pigmentation of the skin. Bilateral tracheobronchitis and acute bronchopneumonia were present. There was no enlargement of the liver or spleen. Microscopic examination of the lungs confirmed the gross diagnosis. The changes seen in the other trunk organs, except the kidneys and liver, were insignificant. The liver showed fatty change of parenchymal cells and some neutral fat deposits within Kupffer-Browicz cells. Occasionally, single macrophages containing neutral fat were seen in the portal tracts. Several macrophages here also contained some granular material strongly positive with periodic acid Schiff reagent and with Sudan Black B. They were also metachromatic with aniline dyes. No metachromatic deposits were seen in the parenchymal cells of the liver. Changes indicative of Niemann-Pick's disease or Gaucher's disease were not found in either 
liver or spleen. Interesting changes were observed in the kidneys. The cytoplasm of cells forming some secondary convoluted tubules, collecting tubules and Henle's loops, contained coarsely granular, strongly eosinophilic material. This was bright rose-pink with PAS reagent and positive in Sudan Black B (fig. 2, Plate LVI). It gave also both pink and brown metachromasia with acetic acid cresyl violet and with tartaric acid thionin. The lumina of some convoluted and collecting tubules contained PAS positive metachromatic deposits which were partially hyaline, partially granular in appearance (fig. 3). The further histochemical analysis of these deposits will be described subsequently.

Nervous system.-On naked eye examination there was severe generalized atrophy of both the cerebral and cerebellar hemispheres. The brain weighed 633 grammes. The leptomeninges were thickened and opaque. The brain as a whole was slightly firmer in consistence than normal. The white matter had a greyish tinge, but there was no definite demyelination. The corpus callosum was very thin, and the ventricles dilated, more so on the left. The brain-stem and spinal cord were unremarkable.

Histopathology of nervous system.-Severe pathological changes were present in both grey and white matter. The cortex showed generalized neuronal loss and its normal laminar pattern was no longer apparent. In some areas status spongiosus involved all cortical layers, while in others it was restricted to one or two layers (fig. 4). These changes were most severe in insular and occipital cortex; no region was spared. All remaining cortical neurones had enlarged, distended cell bodies (fig. 5). Their voluminous cytoplasm contained fine granular accumulations which stained poorly by ordinary methods, were negative in Sudan IV, but strongly positive in Sudan Black B (fig. 6) and in PAS. This stored material completely filled the neuronal cytoplasm, pushing the nucleus towards the cell's periphery, in the majority of cases towards the apical dendrite. Nissl granules were completely lost. The neuronal changes were accompanied by marked glial reaction. Cortical oligodendroglia seemed to be decreased in number. There was intense astrocytic proliferation and hypertrophy. Numerous granular cells filled with yellowish deposits were scattered throughout the cortex. There were only occasional examples of hypertrophied microglial cells. There was considerable fibrogliosis in the cortex, most intense in the superficial cortical layers but, in several regions, involving the whole thickness of the cortex. Generally the intensity and distribution of cortical gliosis corresponded to the intensity of neuronal loss and tissue destruction. The subcortical grey structures were less affected than the cortex. However, they also showed accumulation of granular material within the cytoplasm of neurones, more especially large neurones. This variation in degree of the storage process was well seen in the striatum where small neurones were only slightly affected. The globus pallidus, thalamus, subthalamic nucleus, hypothalamic nuclei, red nucleus and substantia nigra showed an advanced degree of the storage process in their neurones. In all these structures, many macrophages filled with yellowish-brown granular material were present. These nuclei showed moderate fibrogliosis. The same storage process involved neurones throughout the brain-stem and spinal cord. It reached greatest intensity in the motor neurones of the cranial nerves and the anterior horn cells of the spinal cord. Neurones of the posterior root ganglia were also involved.

The centrum ovale was diffusely demyelinated. The degree of demyelination varied, being, in general, more intense in the deeper portions of the hemispheres, and there was some sparing of subcortical fibres (fig. 7). The corpus callosum was entirely devoid of myelin, as were the external and extreme capsules while the internal capsule was only partially demyelinated. In striking contrast to this, the ansa lenticularis, striopallidal fibres, internal and external laminæ of the globus pallidus, fornix, optic tracts and optic radiations were entirely normal in their myelin picture. The pyramidal tracts in the brain-stem and spinal cord were partially demyelinated; other long tracts in the brain-stem showed a much lesser degree of demyelination. The cerebellar white matter 
also showed demyelination. An outstanding feature in the white matter was the presence of numerous, large macrophages scattered throughout the demyelinated areas (fig. 8). In many regions these cells occurred in between remaining nerve fibres; this arrangement was most prominent in dense, oriented white structures, such as the corpus callosum and internal capsule. The cytoplasm of these macrophages contained granules, both coarse and fine, which showed four fundamental staining properties: they were strongly positive in PAS, grey in Sudan Black B, entirely negative in Sudan IV, and metachromatic with aniline dues in acid solution. Their more detailed histochemical characterization will be discussed later. Two types of macrophages were distinguished by their size, distribution and some of their staining properties. One group comprised large round or oval granular cells occurring mainly in the deeper parts of the white matter where demyelination was complete or almost so; the cytoplasm of these cells stained very poorly with ordinary chromatic dyes, having a pale reticulated appearance with hæmatoxylin and eosin and failing to stain with Heidenhain's method for myelin. The other group comprised smaller cells occurring mainly in those areas where myelin breakdown was less advanced such as in the immediately subcortical white matter and around blood vessels; the granular deposits in the cytoplasm of these cells was eosinophilic and took on a deep blue colour with Heidenhain's myelin stain. We consider that the difference between these forms of macrophages resulted from different stages of myelin metabolism. Macrophages were found in all demyelinated areas of the central nervous system, including those areas where myelin breakdown seemed to be secondary, for example the pyramidal tracts. They also occurred in small numbers in sites where myelin was not obviously damaged as, for instance, among the striopallidal fibres. In the cortex, cells of this type were confined to the deeper layers. Small collections of granular, lipid containing material were found lying loose in the tissue. A small amount of sudanophilic material was detected in the perivascular spaces, both loose and within macrophages.

Silver impregnation showed much damage to the axis cylinders in the cerebral white matter. Demyelinated and partially demyelinated regions showed severe diffuse fibrogliosis. We did not find abnormal deposits within the cytoplasm of hypertrophied astrocytes except in one small focus. Oligodendroglial cells were decreased in number in all demyelinated areas and to a lesser degree in some regions where myelin breakdown was partial or had not occurred at all, for instance in the well myelinated striopallidal fibres.

Changes in the cerebellar white matter were similar to those seen in the centrum ovale. The cerebellar grey matter presented distinctive lesions. The granule cell layer was atrophic while the apparently selectively spared stellate cells of Golgi showed cytoplasmic storage. Many Purkinje cells had disappeared, their sites being indicated by empty baskets. The remaining Purkinje cells had distended cell bodies and fusiform swellings of their antler-like dendrites (figs. 9 and 10). Torpedo-shaped deformities were present on Purkinje cell axons within the granular layer (fig. 11). Bergmann's glia was proliferated and there was severe fibrogliosis of the molecular layer. Neurones of the dentate and fastigial nuclei showed storage changes. The cytoplasmic lipids in these deep nuclei were metachromatic.

The optic nerves, despite their well myelinated condition, contained occasional phagocytes filled with metachromatic lipid material. In the retina there was remarkable cellular loss in the outer nuclear layer and many rods and cones had disappeared; the inner nuclear layer was preserved. The ganglion cells were reduced in number, and those remaining were filled with finely granular material which stained positively with PAS and Sudan Black B; it was also faintly metachromatic with aniline dyes (figs. 12 and 13). Granular deposits of melanin pigment were seen scattered throughout the outer nuclear layer of the retina, the picture being that of retinitis pigmentosa. 
Case 3.-At autopsy, carried out about six hours after death, there was severe emaciation and acute bronchopneumonia. Microscopical examination of the kidneys revealed changes identical with those described in Case 2. In the spleen there were occasional clusters of big cells with foamy cytoplasm; some of these gave a positive PAS reaction and stained black with Sudan Black B but were negative in Sudan IV; they were not metachromatic. The liver showed non-specific fatty change of the parenchymal cells. Occasional macrophages containing Sudan Black B and PAS positive material were seen in the portal tracts. The small gall-bladder was almost filled by a villous papilloma; numerous macrophages were present in its stroma and these contained lipid material with the same staining properties as that in the renal tubules (fig. 14). The other body organs were unremarkable.

Nervous system.-The brain was atrophic, weighing 695 grammes; this atrophy involved both cerebral and cerebellar hemispheres which were unusually firm. The leptomeninges were thickened and had a greyish tinge. The white matter was brownishgrey, but there was no evident demyelination on naked eye examination. The cortex in many areas seemed to be thinner than usual; in several places its inner border was not sharply defined. The ventricular system was symmetrically dilated. There were numerous heterotopic foci of grey matter in the ventricular walls bilaterally, mainly in posterior and inferior horns of the lateral ventricles (fig. 15). The brain stem and spinal cord were grossly unremarkable.

Histopathology of nervous system.--The microscopical findings in the nervous system were similar to those of Case 2 and we will therefore mention only the minor differences in intensity and distribution of the lesions. In Case 3, destruction of grey matter was more widespread and status spongiosus involved the whole thickness of the cortex more extensively (fig. 16). The caudate nucleus and putamen were involved while the globus pallidus and thalamus showed only a minor degree of neuronal loss. As in Case 2 the neuronal storage process was widespread and preferentially involved large neurones (fig. 17). Cerebellar involvement was more intense, especially in the palæocerebellum.

In contrast to the grey matter involvement, the white matter lesion was less marked than in Case 2. Areas in which demyelination was not complete were more numerous and this feature was most noticeable in the immediately subcortical white matter. Axis cylinder damage, however, appeared to be similar in degree. Macrophages containing eosinophilic material were more numerous and, in a greater proportion of them, this gave the staining reactions of normal myelin. Amongst these cells, more showed purple metachromasia with aniline dyes and fewer gave brown metachromasia. Changes in the optic nerves were similar to those in Case 2. The retinæ were not examined.

\section{HistochemicAl OBSERVATIONS}

Histochemical studies were carried out in order to determine the nature of substances accumulated in various sites and to assess possible chemical relationships between them. In addition to the brain and spinal cord, studies were made of those body organs which, in ordinary chromatic stains, showed changes which were thought to be related to the fundamental pathological process. Table I gives a list of the methods used. Table II summarizes the histochemical findings in the nervous system. The histochemical properties of abnormal deposits in the retina, gallbladder and kidneys are presented in Table III. 
TABLE I

HISTOCHEMICAL METHODS USED

\begin{tabular}{|c|c|}
\hline STAINING METHOD & SUBSTANCES SHOWN \\
\hline 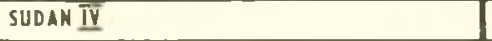 & NEUTRAL FATS, CHOLESTEROL ESTERS \\
\hline SUDAN BLACK B & LIPIDS \\
\hline PERIODIC ACID-SCHIFF (PAS) & POIYSACCHARIDES, GLYCOPROTEINS EIC. \\
\hline PERPORMIC ACID-SCHIFF (PTAS) & LIPIDS CONTAINING UNSATURATED BONDS \\
\hline ACEIIC ACID-CRESYL VIOLET (PEIFFER-HIRSCH) & METACHROMASIA (CEREBROSIDE SULPHURIC ACID-ESTERS) \\
\hline TOLUIDIME BLUE-STANDARD & METACHROMASIA \\
\hline FEYRTERS "MOUNTING" METHOD & METACHROMASIA-ACIDIC LIPIDS \\
\hline ORCIN-HYDROCHLORIC ACID-METHOD & MEURAMINIC ACID (GANGLIOSIDES) \\
\hline COPPER-PHTHALOCYANIN METHOD (KLUUVR) & CHOLINE CONTAINING PHOSPHATIDES \& GIYCOLIPIDS \\
\hline ALCIAN-BLUE METHOD (LISON) & ACID MUCOPOLYSACCHARIDES \\
\hline OKAMOIO-SHIMAMOTO-UEDA METHOD & PHOSPHOLIPIDS AND CEREBROSIDES \\
\hline OKAMOIO.SHIMAMOTO METH. AFTER PYRIDINE & PHOSPHOLIPIDS \\
\hline OKAMOTO-SHIMAMOTO METH. AFTER ETHER & SPHINGOMYELIN \\
\hline COUPLED TETRAZONIUM REACTION-DANIELII & AROMATIC AMINO ACIDS (PROTEINS) \\
\hline COUPLED TETRAZONIUM REACTIOH-BENZOYIATIOH & POLYMERISATION OF PROTEINS \\
\hline MILLON'S REACIION & TYROSINE (PROTEINS) \\
\hline
\end{tabular}

The solubility of the abnormal metabolic products in water, cold and warm $\left(60^{\circ}\right)$ acetone, ether, ethanol, methanol, petroleum ether, pyridine and a $2: 1$ mixture of chloroform and methanol was studied and the results are summarized in Table IV. In general, none of the solvents used abolished the capacity of the deposits to stain with Sudan Black B and with PAS. However, incubation in the chloroform-methanol mixture, hot acetone, absolute alcohol, petroleum-ether and in pyridine decreased the staining intensity of granular material both in macrophages and in neurones. These solvents completely abolished staining of extracellular granular material. We explain this phenomenon by the binding of stored intracellular deposits with cell protein, whereas the extracellular granules are not so bound. The positive coupled tetrazonium reaction of the intracellular deposits contrasted with the negative reaction extracellularly supports this explanation.

The metachromasia of lipids accumulated in macrophages was an outstanding feature in our cases. Despite generalized storage change in neurones, metachromasia of neuronal deposits occurred only in some nuclear groups; they were the dentate nucleus, globus pallidus, large pyramidal cells of the cortex and motor neurones of the spinal cord (fig. 18). With acetic acid cresyl violet (Peiffer and Hirsch, 1955), the metachromasia was purple and brown. The brown metachromasia occurred mainly in those areas where demyelination was more advanced, whereas purple metachromasia was seen in less demyelinated areas. When stained 
TABLE II

HISTOCHEMICAL PROPERTIES OF SUBSTANCES ACCUMULATED IN NERVOUS SYSTEM

\begin{tabular}{|c|c|c|c|c|c|}
\hline \multirow{2}{*}{ METHOD USED } & \multicolumn{2}{|c|}{ GRAY MATTER } & \multicolumn{3}{|c|}{ WHITE MATTER } \\
\hline & MEURONE & MTRACHR MENOONES & LARGI MACLOPHAG. & STAL mA OOPHAG & Fil dposms \\
\hline SUDAK TV & - & - & - & - & - \\
\hline SUDAN BLACK B & +++ & $++t$ & + & ++ & ++ \\
\hline PAS & +++ & $++t$ & +++ & +++ & +++ \\
\hline PAS & ++ & ++ & ++ & ++ & ++ \\
\hline PiAS & - & - & - & - & - \\
\hline ACETIC-ACID CRESYL VIOLET & - & + & $++t$ & $+t+$ & +++ \\
\hline TOLUIDINE BIUE-STANDARD & - & + & $+t+$ & +++ & +++ \\
\hline FEYRTER'S MOUNTING METHOD & + & ++ & +++ & +++ & +++ \\
\hline ORCIN-HYOROCHLORIC ICID & + & + & - & - & - \\
\hline $\begin{array}{l}\text { ORCIN-HYOROCHLORIC ACID } \\
\text { Paralfin }\end{array}$ & + & + & - & - & - \\
\hline COPPER-PHTHALOCYANIN Paralfín & ++ & ++ & + & + & + \\
\hline ALCIAN BLUE $\quad$ Paraffin & + & + & - & + & + \\
\hline ОКАМОТО МЕТН. & ++ & ++ & +++ & +++ & +++ \\
\hline $\begin{array}{c}\text { OKAMOIO METH. AFYER PYRIDINE } \\
\text { FrOZON }\end{array}$ & ++ & ++ & - & + & - \\
\hline 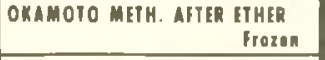 & + & + & - & + & - \\
\hline COUPLED TETRAZONIUM Paraflin & ++ & ++ & ++ & ++ & - \\
\hline $\begin{array}{r}\text { COUPLED TETRAZONIUM, BENZOYI } \\
\text { Paraflia } \\
\end{array}$ & $+t$ & ++ & ++ & ++ & - \\
\hline MILLON'S METH. & + & + & + & + & - \\
\hline $\begin{array}{l}+ \text { Fainfly posillya } \\
++ \text { Positive }\end{array}$ & Sirongl & sitive & $\overline{0}$ & $\begin{array}{l}\text { lative } \\
\text { nol done }\end{array}$ & \\
\hline
\end{tabular}

by Feyrter's method (thionin in 0.5 per cent tartaric acid), the granular cells gave brown metachromasia as in the Peiffer-Hirsch preparations; neurones in general, including Purkinje cells and their distended dendrites, showed pink-violet coloration. The remaining myelin took as a rule a purple colour in acidic cresyl violet and tartaric thionin, but in some areas it was definitely brown, resembling the lipid deposits in granular cells. Metachromasia of granular cells disappeared entirely after one-and-a-halfhour incubation in pyridine, chloroform-methanol, chloroform-ethanol, and almost entirely after absolute alcohol and hot acetone. Cold acetone and ether did not have any influence on this staining phenomenon.

Sections examined in polarized light showed birefringence of abnormal 
TABLE III

HISTOCHEMICAL PROPERTIES OF SUBSTANCES ACCUMULATED IN VISCERA AND RETINA

\begin{tabular}{|c|c|c|c|}
\hline METHOD USED & $\begin{array}{c}\text { KIDNEYS } \\
\text { / cases } 2+3 /\end{array}$ & $\begin{array}{c}\text { GALL BLADDER } \\
\text { /case } 3 /\end{array}$ & $\begin{array}{l}\text { RETINA } \\
\text { / case 2/ }\end{array}$ \\
\hline SUDAN IY & - & 0 & - \\
\hline SUDAN BLACK B & + & ++ & $++t$ \\
\hline PAS & +++ & +++ & $+t+$ \\
\hline PIAS & - & - & - \\
\hline ACETIC ACID CRESYL VIOLET & $++t$ & 0 & ++ \\
\hline TOLUIDINE-BLUE STANDARD & ++ & 0 & 0 \\
\hline FEYRTER'S "MOUNTING' METHOD & +++ & 0 & + \\
\hline ORCIN-HYDROCHLORIC ACID & - & - & \pm \\
\hline COPPER-PHTHAL OCYANIN & + & + & ++ \\
\hline ALCIAN BLUE & \pm & + & \pm \\
\hline ОКАМОГО МЕТН. & +++ & 0 & 0 \\
\hline OKAMOTO METH. AFTER PYRIDINE & + & 0 & 0 \\
\hline OKAMOTO METH. AFTER ETHER & + & 0 & 0 \\
\hline COUPLED IETRAZONIUM & ++ & ++ & ++ \\
\hline COUPLED TETRAZ. BENZOYL. & ++ & ++ & ++ \\
\hline MILLON'S METH. & + & + & + \\
\hline $\begin{array}{l}+ \text { Faintly positive } \\
++ \text { Positive }\end{array}$ & $\begin{array}{c}+++ \text { Strongly } \\
\pm \quad \text { Doubiful }\end{array}$ & $\begin{array}{l}\text { ositive } \\
\text { esult }\end{array}$ & $\begin{array}{l}\text { Negative } \\
\text { Test not done }\end{array}$ \\
\hline
\end{tabular}

TABLE IV

EFFECT OF DIFFERENT SOLVENTS ON STAINING PROPERTIES OF LIPID DEPOSITS

\begin{tabular}{|c|c|c|c|c|c|c|c|c|c|}
\hline \multirow{2}{*}{ SOLVENT } & \multicolumn{3}{|c|}{ PERIODIC ACID SCHIFF } & \multicolumn{3}{|c|}{ SUDAN BLACK B } & \multicolumn{3}{|c|}{ METACHROMASIA } \\
\hline & Meunonts & macnOPHAGES & Thit aposms & MEUROHES & MACROPHAGES & HII UEP OSIIS & MEUIOMIS" & achormages & Iall derosiss \\
\hline WATER & + & + & + & + & + & + & + & + & + \\
\hline ETHER & + & + & + & + & + & + & + & + & + \\
\hline ACETONE-cold & + & + & + & + & + & + & + & + & + \\
\hline ACETONE-hot & + & + & tred & + red & + red & - & tred & tred & + red \\
\hline ALCOHOL & + red & tred & - & tred & tred & - & - & - & - \\
\hline PETROLEUM-EHER & + & + & + red & tred & + red & - & 0 & 0 & 0 \\
\hline PYRIDINE & + red & tred & - & tred & t red & - & - & - & - \\
\hline CHLOROFORM-METHANOL & tred & tred & - & tred & + red & - & - & - & - \\
\hline CHLOROPORM-EHANOL & 0 & 0 & 0 & 0 & 0 & 0 & - & - & - \\
\hline
\end{tabular}

lipids in granular cells of the white matter when stained with aniline dyes and with Sudan Black B. The effect of solvents on this birefringence is summarized in Table V. The accumulated material within neurones was not birefringent. In PAS stain, neither neurones nor macrophages showed birefringence. In the white matter birefringent sheaths were seen 
TABLE V

EFFECT OF DIFFERENT SOLVENTS ON THE BIREFRIGENCE OF LIPID DEPOSITS

\begin{tabular}{|c|c|c|c|c|c|c|c|c|c|}
\hline \multirow{2}{*}{ SOLVENT } & \multicolumn{3}{|c|}{ METACHROMASIA } & \multicolumn{3}{|c|}{ SUDAN BLACK B } & \multicolumn{3}{|c|}{ PERIODIC ACID SCHIFF } \\
\hline & NEUROMES & MACIOPHAGIS & BRER DEPOSITS & Meuromis & MACROPHAGE & GRII DIPOSITS & Mร1Rones & MECROPHAGES & Fill deposits \\
\hline WATER & - & + & + & - & + & + & - & - & - \\
\hline ETHER & - & + & + & - & + & + & - & - & - \\
\hline ACETONE-cold & - & + & + & - & + & + & - & - & - \\
\hline ACETONE-hot & - & \pm & - & - & \pm & - & - & - & - \\
\hline ALCOHOL & - & - & - & - & - & - & - & - & - \\
\hline PETROLEUM-ETHER & - & - & - & - & + & - & - & - & - \\
\hline CHLOROFORM-MЕHANOL & - & - & - & - & - & - & - & - & - \\
\hline PYRIDINE & - & - & - & - & - & - & - & - & - \\
\hline
\end{tabular}

surrounding axis cylinders which appeared to be devoid of myelin in ordinary methods. This phenomenon may be analogous to that described by Seitelberger (1960) in cases of Pelizaeus-Merzbacher disease, where demyelinated axis cylinders had a birefringent investment.

\section{BIOCHEMICAL STUdiES}

Portions of the cerebral white matter and of the cerebral cortex were examined. Material from Case 2 was formalin fixed, while the portion of brain from Case 3 had been placed in the deep freeze at $-20^{\circ} \mathrm{C}$. and was dispatched by air and received still frozen. The lipid extracts were prepared using the technique of Folch et al. (1957a) employing a $2: 1$ chloroform-methanol (v/v) solvent mixture.

Water content, total phospholipid, sphingomyelin, total and free cholesterol were estimated as previously (Cumings, 1953). Total hexosamine and neuraminic acid were determined (Cumings, 1957), as were neutral cerebrosides (Radin et al., 1955). Sulphatides were estimated by precipitating them as the barium salt using the technique of Radin et al. (1957) and the calculation was based on the formula of cerebron sulphuric acid as given by Folch et al. (1957b).

The results of these examinations on the brains of these 2 cases are given in Table VI. The figures obtained in Case 2 show in both the white matter and the cortex a very great loss of total phospholipids, a less severe loss of sphingomyelin and of cholesterol but with no significant amount of esterified cholesterol together with a normal water content. There is an apparently normal level of neuraminic acid (i.e. ganglioside) in the cerebral cortex but there is a definitely increased amount of total hexosamine in the white matter. The actual figure for sulphatides is normal, but, in view of the very gross loss of other lipids, must be considered as being abnormal.

In some respects there is less damage in Case 3 as evidenced biochemically. There is a small degree of loss of total phospholipids, less marked in the cortex than in the white matter. The same is true of the sphingomyelin 
TABLE VI

CEREBRAL LIPIDS IN TWO OF THE CASES

\begin{tabular}{|c|c|c|c|c|}
\hline \multirow{2}{*}{ SUBSTANCE } & \multicolumn{2}{|c|}{ Case 2. Age 5 Years } & \multicolumn{2}{|c|}{ Case 3 Age 3 Years } \\
\hline & WHITE MATTER & CORTEX & WHITE MATTER & CORTEX \\
\hline TOIAL PHOSPHOLIPIDS & 5.45 & 6.31 & 14.18 & 17.81 \\
\hline SPHINGOMYELIN & 1.53 & 1.47 & 3.85 & 3.21 \\
\hline TOTAL CHOLESTEROL & 6.08 & 5.47 & 6.84 & 6.14 \\
\hline ESTERIFIED CHOLESTEROL & 0.22 & 0.15 & 0.20 & 0.23 \\
\hline TOTAL HEXOSAMINE & 0.44 & & 0.57 & \\
\hline NEURAMIMIC ACID & & 0.18 & & 0.46 \\
\hline MEUTRAL CEREBROSIDES & 2.3 & & 3.43 & \\
\hline SULPHATIDES & 1.8 & & 6.30 & \\
\hline WATER \% & 77.8 & 81.0 & 75.6 & 82.6 \\
\hline
\end{tabular}

and total cholesterol levels, and as in the other patient there is no significant amount of esterified cholesterol present. Neuraminic acid in the cortex is hardly raised above the normal level which at the age of this patient would be around 0.40 gramme per 100 grammes dry tissue (Cumings et al., 1959). Total hexosamine in the white matter is very considerably increased (normal for age 0.30 gramme per 100 grammes dry tissue). Neutral cerebrosides are within the normal range but sulphatides in the white matter are very considerably increased, being nearly four times the normal figure for this age.

\section{Discussion}

Morphologically, the cases in our series appear to present the elements of two diseases, metachromatic leucodystrophy and familial amaurotic idiocy. The intensity of neuronal lipid storage and its distribution suggest a late infantile form of amaurotic idiocy in which the storage process never produces the degree of cellular distension seen in the infantile form (Seitelberger, et al., 1957 and 1958; Diezel, 1960). The cerebellar lesions also support a diagnosis of the late infantile form. Although in none of our cases were retinal changes seen during life, the finding of pigmentary degeneration of the retina at autopsy on Case 2 is supportive evidence for this diagnosis. On the other hand, the diffuse demyelination of white matter in both cerebral and cerebellar hemispheres, accompanied by the presence of non-sudanophilic lipid deposits, classifies our cases as a form of diffuse sclerosis conforming, in general, to the type first described by Scholz (1925 and 1933). The outstanding morbid anatomical feature 
of Scholz's original cases, as well as of those subsequently described (Bielschowsky and Henneberg, 1928; van Bogaert and Scholz, 1932; van Bogaert and Bertrand, 1933; and others) was diffuse demyelination of the white matter with non-sudanophilic myelin breakdown products. The metachromasia present in our cases permits us to classify them as belonging to the metachromatic subgroup of leucodystrophy, as described by Einarson and Neel (1938), Wicke (1938), van Bogaert and Dewulf (1939), Brandberg and Sjövall (1940), Norman (1947), Brain and Greenfield (1950), Leslie (1952), Feigin (1954), Diezel and Richardson (1957), Wohlwill and Paine (1958), Hain and LaVeck (1958), Jervis (1958, 1960), Jefferson (1958), Peiffer (1959). Subsequent examination by Edgar (1955b), Hirsch and Peiffer (1955 and 1957) and by Diezel and Richardson (1957) showed that the majority of cases previously described as being of Scholz type had in fact, metachromatic properties. As in other cases of metachromatic leucodystrophy (Wicke, 1938; Norman, 1947; Brain and Greenfield, 1950; Leslie, 1952; Bertrand et al., 1954; Einarson, 1954; Austin, 1957 and 1960; Jervis, 1958 and 1960; Hain and LaVeck, 1958) our cases had abnormal lipid deposits in some of the viscera. Like Brain and Greenfield (1950), Bertrand et al. (1954), and Diezel (1957), we observed metachromatic deposits in the peripheral nervous system.

The intensity of cortical destruction in our Cases 2 and 3 is unusual, and we are inclined to attribute it to combined involvement of neurones and subcortical nerve fibres. Oligodendroglia had almost completely disappeared from demyelinated areas and were much reduced in areas of partial demyelination; in a few, apparently well-myelinated areas oligodendroglia were reduced in number but this phenomenon to which Greenfield (1933) first drew attention, was not prominent.

The question arises whether our observations establish the presence in these cases of the lesions of both metachromatic leucodystrophy and amaurotic idiocy or whether we are here presented with an extreme degree of secondary demyelination in otherwise typical amaurotic idiocy. Some degree of demyelination is so common in amaurotic idiocy that cases without demyelination can be considered as rare. However in the published cases of familial amaurotic idiocy describing demyelination (Sachs, Bielschowski, Globus-quoted by Bérard-Badier, et al., 1958; van Bogaert and Bertrand, 1933; Bird, 1948; Einarson, 1951; Leslie, 1952; Seitelberger, 1957 and 1958; Favarger and Wildi, 1957; Jervis, 1958; Benda and Melchior, 1958), the myelin breakdown products were sudanophilic. In the cases of Ostertag (1925), and Bérard-Badier et al. (1958), in addition to sudanophilic deposits, collections of "prelipids" were observed; however, even in these, the lipid deposits were not metachromatic. So far as we are aware, metachromatic lipid deposits have not been observed in the viscera in cases of amaurotic idiocy. 
An alternative possibility is that the present cases are examples of metachromatic leucodystrophy in which neuronal changes are unusually advanced and widespread. However, despite the known variability of neuronal involvement, we have been unable to find in the literature cases of metachromatic leucodystrophy in which lipid storage involved neurones of all grey structures. We were not able to get a detailed pathological description of the case, mentioned by Einarson in his paper of 1951, in which a combination of the pathological changes of metachromatic leucodystrophy and amaurotic idiocy was mentioned. Moreover, in our cases metachromasia of the product stored in neurones was strictly confined to those nuclear groups in which it is commonly present in metachromatic leucodystrophy, while the Schaffer-Spielmeyer degeneration involved all neurones of the central nervous system.

Our cases, then, combine the complete pathological picture of both diseases. They occupy, from the morphological point of view, a central position between those lipidoses in which the leucodystrophic elements are most advanced (Ostertag, 1925; Bérard-Badier et al., 1958) and those metachromatic leucodystrophies in which the intensity of the lipidotic features is greatest. Peiffer's (1959) case with cerebellar changes, and Einarson's (1951) and Leslie's (1952) cases with diffuse cortical storage degeneration most nearly approximate to ours.

Cerebellar changes are quite common in leucodystrophies (Poser, Dewulf and van Bogaert, 1957). Lesions of the cerebellar cortex were furthest advanced in one of Peiffer's (1959) cases where, in addition to intense atrophy of the granular layer, there were also Purkinje cell lesions. These changes, however, still fell short of those present in our cases.

We will discuss separately the results of our histochemical investigation of the deposits within neurones and within macrophages in the white matter.

First neurones: the negative results with Sudan IV enable us to rule out neutral fats and cholesterol esters as materials accumulated within neurones. The faint yellow-orange colour with Sudan IV in Case 1 is that seen with "prelipids." The strongly positive reaction with Sudan Black B (figs. 6 and 19) indicates the lipid nature of the accumulated material, and the relative resistance of this reaction to the activity of fat solvents suggests that the lipid is somehow bound into the cellular structure. On the basis of the Millon and of the Danielli reactions, we suppose that cellular proteins are the binding factor. The reduction in intensity of the Sudan Black B reaction following incubation in such fat solvents as absolute alcohol, petroleum ether, pyridine and a mixture of chloroform and methanol indicates the presence of some admixed lipid which is not bound with protein. The positive reaction with PAS shows that the stored material also contains a carbohydrate component. Simultaneous negative 
PfAS indicates that the PAS reaction is due to carbohydrate, not to unsaturated lipid. The striking parallelism in the decrease of staining intensity with Sudan Black B and with PAS after incubation in different fat solvents indicates a close linkage between the carbohydrate and lipid components of the accumulated material. The positive, although weak, reaction with Alcian blue indicates the presence of acidic groups in the stored material. Moreover, these substances give pink-red metachromasia in Feyrter's tartaric acid thionin. On the basis of these staining properties, we can define the accumulated material as an acid glycolipid, partially free, partially bound with protein. Of the two groups of glycolipids known to occur in the nervous system, namely gangliosides and cerebrosides, only gangliosides contain neuraminic acid. In our series, the Bial reaction for neuraminic acid was very weak in both paraffin and frozen sections. This result surprised us, as the material stored within neuronal cytoplasm in cases of familial amaurotic idiocy has been considered (Diezel, 1954 $a$ and $b$; Klenk, 1954; Seitelberger et al., 1957) to belong to the gangliosides. More recently, however, Diezel (1960) has stated that, in the infantile form of amaurotic idiocy, the stored material is a neuraminic acid-free glycolipid which is considered by him to be a precursor of ganglioside; this substance, however, is readily soluble in fat solvents, not bound with protein and is confined to the infantile form of the disease, while our cases belong to the late infantile form. Theoretically we might suppose that our series represent a transitional form in which the accumulated glycolipids have formed the linkage with proteins but have not yet become attached to neuraminic acid. Alternatively, the faintness of the Bial reaction could be due to prolonged fixation in formalin (over one year), and/or to the presence of myelinogenic lipids in the white matter which probably inhibit the orcin-hydrochloric acid reaction. Several cases of morphologically typical amaurotic idiocy have been reported in which there was no increase of gangliosides but instead an accumulation of cerebrosides (Favarger and Wildi, 1957). In addition to the major stored material, we were able to establish the presence of some additional substances, amongst them, sphingomyelins; their presence was indicated by the persistent positivity of the Okamoto, Shimamoto and Ueda reaction after incubation in ether. The strongly positive original Okamoto reaction, resistant to pyridine but weakened by ether indicates that, in addition to sphingomyelins, some other phospholipid was stored. The material present within the neuronal cytoplasm of the dentate nuclei, globus pallidus, anterior horn cells of the spinal cord and pyramidal cells of the cerebral cortex differs from that in other neurones only in the occurrence of purple and brown metachromasia with acetic acid cresyl violet and tartaric acid thionin, other staining properties being identical with those in the remaining neurones. We interpret this finding as indicating the presence in these neuronal groups, of a lipid with the same solu- 
bility and staining properties as that accumulated in the granular cells of the white matter; it is small in amount, the metachromasia never reaching the intensity seen in the granular cells.

The substances accumulated in the cytoplasm of the retinal ganglion cells have the same histochemical properties as those in neurones showing metachromasia. This is in accord with the observations of Cogan and his colleagues (1958).

White matter: The deposits in the white matter, both free and in macrophages, were negative in Sudan IV but positive with Sudan Black B (fig. 20); their PAS positivity was even more prominent than that of the neuronal deposits (fig. 21). This material is therefore also a glycolipid. Both the Millon and the Danielli reactions indicate a linkage of this material with protein when within macrophages but the extracellular granules were negative in both these tests. In contrast to the neuronal deposits, Bial's reaction was entirely negative in the white matter so that neuraminic acid must be considered absent in this situation. The occurrence of purple and of brown metachromasia in the white matter deposits was an even more distinctive property (fig. 22). The strongly positive Okamoto, Shimamoto and Ueda reaction of the large macrophages, disappearing completely after incubation in pyridine, indicates that the glycolipid which they contain is a cerebroside. The small macrophages showed minor differences in that their content gave a positive reaction with Alcian blue and remained slightly positive in the Okamoto reaction after pyridine and after ether; these properties indicate that there is some admixture of sphingomyelins and other phospholipids; positive staining with copper phthalocyanin supports this view.

The abnormal lipid deposits in the kidneys, liver and biliary tract had similar histochemical properties to those in the white matter.

In summary we may say that, while our investigation does not uniquely define the chemical nature of the substances accumulating in our cases, it does enable us to classify them. They are glycolipids, in great part bound with protein. Most of the material accumulated within neurones belongs to the gangliosides (despite the weak Bial reaction) or is formed by a substance intermediate between gangliosides and cerebrosides. The substances present in the white matter seem to be rather more close to cerebrosides. Because of their metachromasia, we can consider them as a sulphuric acid ester of cerebrosides (Jatzkewiz, 1958; Wislocki and Singer, 1950; Austin, 1957 $a$ and $b$ and 1960). There are undoubtedly other substances present and the product stored in both neurones and granular cells in the white matter is not a homogeneous lipid but a mixture of lipids.

The histochemical studies reported by different authors have shown some differences in staining properties in cases of amaurotic idiocy. In meta- 
chromatic leucodystrophy histochemical variations have also been found. While these differences may depend in part on variations in histochemical technique, other more important factors probably operate. These include changes in the solubility of lipids under the influence of their linkage with cellular protein and the inhibition of the Bial reaction by myelin breakdown products. These differences may also be due to the different chemical structure and nature of the lipids accumulated in different cases. We do not feel, however, that these histochemical variations provide adequate reason to consider the conditions as distinct. Numerous biochemical investigations support this view and suggest the existence of mixed and transitional forms of storage disease.

Edgar (1956) has stressed that we cannot separate the pathophysiology of the component parts of the nerve cell, that is its pericarion and processes, and it seems reasonable to extend this principle to the myelin sheath which is so intimately related to the axis cylinder. The role of the axis cylinder in the normal production and maintenance of myelin is well known and it seems logical to suppose that similar or even identical enzyme systems manage lipid metabolism throughout the neurone-myelin sheath complex. Moreover the lipids involved are chemically similar, belonging to the sphingolipid group. In addition, Klenk's observations suggest that the myelin lipids may be derived from gangliosides. A genetically determined alteration of an enzyme system concerned in the metabolism of sphingolipids might produce changes in the whole group, leading to disease states in which the biochemical and histopathological features varied according to the position of the altered link in the enzyme system; it might for example result in alteration mainly of cellular lipids as in amaurotic idiocy or of myelin lipids as in metachromatic leucodystrophy. A mechanism of this type would account for deposits of lipid normally foreign to their site, e.g. sphingomyelins within the neuronal cytoplasm (Diezel, 1954 and 1960; Seitelberger, 1957) in the case of amaurotic idiocy or neuraminic acid and hexosamines in the white matter in metachromatic leucodystrophy (Brante, 1952; Edgar, 1955b and $1957 a$ and $b$; Cumings, 1957 and 1960a; Svennerholm, 1957). Such a hypothesis also suggests the possible existence of intermediate forms of the diseases showing simultaneously alterations in both cellular and myelin sheath lipids. Our cases seem to us to occupy just such a position. The difference in histochemical properties of substances accumulated within neurones and granular cells of the white matter are a gauge of the difference between normal lipid components of the pericarion and of the myelin sheath.

The presence of strong brown metachromasia in apparently undamaged myelin sheaths in one of our cases (Case 2) supports Diezel's (1960) view that a metabolic abnormality in myelin sheaths precedes their destruction and the accumulation of abnormal products in granular cells. This evi- 
dence of accumulation in both myelin sheaths and in phagocytes is the basis for the now accepted view that metachromatic leucodystrophy is rather a form of storage disease than a demyelinative disorder.

Edgar (1957) found a raised level of lipid hexosamine in the white matter of eleven cases, but the material had been stored in formalin over many years. A similar finding, except that total hexosamine was determined, has been found in a number of other cases (Cumings, 1957, 1960a; Black and Cumings, 1961; Tingey, 1959).

Austin (1957a) found metachromatic material in the urine, which was thought to be specific for the condition of metachromatic leucodystrophy and similar findings have been found by other workers (Cumings, 1960b, 1961). Jatzkewitz $(1958,1960)$ claimed to have isolated a cerebroside sulphuric acid ester in increased amounts in 2 cases, one of whom had been described clinically and histologically by Peiffer (1959) and biochemically by Cumings (1960a), and this increase was especially noticeable when the sulphatide fraction was related to the amount of the total sphingolipid present. Austin (1960) in 4 cases of metachromatic leucodystrophy found in the 3 brains examined by chemical methods an increase in cerebroside sulphuric acid esters. Hagberg et al. (1960) in 2 cases found very considerably raised levels of cerebroside sulphuric acid as well as increased amounts of hexosamine in the cerebral white matter. In 1960 one of us described 4 other cases verified by histological examination in all of whom raised levels of total hexosamine were found, while in 3 of these cases increased quantities of sulphatides were present (Cumings, 1961). Similar findings have also been recorded by other workers (Norman et al., 1960; Black and Cumings, 1961). The 2 cases described here on which biochemical analysis of the brain was possible demonstrate the diagnostic lipid abnormalities of metachromatic leucodystrophy or sulphatide lipidosis, the name of the condition suggested by Austin (1960), for there was in these cases an increase of hexosamine and of sulphatide with loss of myelin lipids.

The chemical analysis revealed in Case 2 an apparent loss of gangliosides but in view of the very considerable reduction of other lipid compounds this low figure may not represent the true state of affairs. Case 3 , however, did not show a significantly increased amount of ganglioside in the cortex as compared with a normal and the level is not as high as would be found in a patient of this age with amaurotic family idiocy.

The biochemical findings suggest that these 2 cases fall into the group of metachromatic leucodystrophy or sulphatide lipidosis and that the derangement is one in which there is some abnormality in one of the myelin components and this abnormality would appear less likely to be one resulting from an unusual demyelination than a consequence of a faulty formation of myelin in that a greater amount of a lipid material normally present is found in the cerebral white matter. 
The constancy of the neuronal groups involved in metachromatic storage is striking and implies some common factor in their metabolism differentiating them from other neurones. These groups are also subject to early and severe lipochrome degeneration and, while the mechanism of this is no doubt different, it probably reflects an analogous metabolic peculiarity.

The significance of changes in the viscera in the forms of lipidosis under discussion is controversial. Witte (1921), who found metachromatic deposits in various trunk organs in metachromatic leucodystrophy, suggested that they resulted from a generalized metabolic disturbance rather than a primarily cerebral disease. Austin holds a similar opinion. Other authors such as Brain and Greenfield, Norman, Leslie, Adams and Kubik (1952) who found metachromatic deposits only in some viscera with an excretory function, consider the process as primarily cerebral with secondary excretion of the abnormal products. Those cases in which visceral deposits were not found (van Bogaert and Dewulf, 1939) support the second possibility. In our cases the localization of abnormal deposits in the biliary and renal tracts, with histochemical properties identical to those of the white matter deposits, strongly incline us to this latter view, and we believe that the metachromatic nephrosis results from excretion of the cerebral products. The same holds true for the biliary tract. In this connexion it is noteworthy that a papilloma of the gallbladder, such as was present in our Case 3, was also found by Norman (1947) in one of his cases. The accumulation of macrophages filled with metachromatic substances in perivascular spaces in the brain suggests transport to the blood stream, while the metachromatic granulation in leucocytes, emphasized by Austin (1958), probably results from the well-known phagocytic properties of the granulocytes. Metachromatic deposits in the Kupffer cells of the liver can be similarly explained.

\section{SUMMARY}

(1) An account is given of 3 siblings with a progressive neurological disease in each of which there was histopathological evidence of both amaurotic idiocy and metachromatic leucodystrophy.

(2) The histochemical nature of the accumulated substances was investigated. Those found in the cytoplasm of neurones are considered to be mainly gangliosides or some glycolipids intermediate between gangliosides and cerebrosides. Those accumulated in the white matter are considered to be cerebrosides or cerebroside sulphuric acid esters. Evidence is given that there was an admixture of other lipids.

(3) Biochemical studies on tissue from 2 of the cases shows, in the white matter, an increase in hexosamine in both and an increase in sulphatides, absolute in one case and relative to the total lipid content in the other case. The neuraminic acid content of the cortex does not appear to be increased. 
(4) It is suggested that a unitary, genetically determined abnormality of brain lipid metabolism underlies both conditions.

(5) Changes in the viscera, present in 2 of the cases, are believed to be secondary to the excretion of products of abnormal cerebral lipid metabolism.

\section{ACKNOWLEDGMENTS}

We are indebted to Dr. J. P. Robb who looked after these patients clinically and to Dr. G. C. McMillan in whose Department of Pathology the necropsies were performed. We are also indebted to Mr. H. Goodwin for technical help.

\section{REFERENCES}

Adams, R. D., and KubiK, C. S. (1952) Amer. J. Med., 12, 510.

Austin, J. H. (1957a) Neurology, 7, 415.

(1957b) Neurology, 7, 716.

(1958) Trans. Amer. neurol. Ass., p. 149.

(1960) Neurology, 10, 470.

Benda, C. E., and Melchior, J. C. (1958) J. Neuropath., 17, 205.

Bérard-Badier, M., Paillas, J. E., Gastaut, H., and Edgar, G. W. F. (1958) Psychiat. et Neurol., 135, 50.

Bertrand, I., Thieffry, S., and Bargeton, E. (1954) Rev. neurol., 91, 161.

Bielschowsky, M., and Henneberg, R. (1928) J. Psychol. Neurol., Lpz., 36, 131.

BIRD, A. (1948) Brain, 71, 434.

Black, J. W., and Cumings, J. N. (1961) J. Neurol. Neurosurg. Psychiat. In press.

van Bogaert, L., and Scholz, W. (1932) Z. ges. Neurol. Psychiat., 141, 510.

--, and BertRAND, Y. (1933) Rev. neurol., 40, (ii), 249.

-_, and Dewulf, A. (1939) Arch. Neurol. Psychiat., Chicago, 42, 1083.

Brain, W. R., and Greenfield, J. G. (1950) Brain, 73, 291.

Brandberg, O., and Suövall, E. (1940) Z. ges. Neurol. Psychiat., 170, 131.

Brante, G. (1952) Scand. J. clin. Lab. Invest., 4, 43.

Cogan, D. G., Kuwabara, T., Richardson, E. P., and Lyon, G. (1958) A.M.A. Arch. Ophthal., 60, 397.

Cumings, J. N. (1953) Brain, 76, 551.

- (1957) In van Bogaert's “Cerebral Lipidoses." Oxford, p. 112.

(1960a) In Cumings" "Modern Scientific Aspects of Neurology." London, p. 330.

(1960b) Psychiat. Neurol. Neurochir., 63, 110.

(1961) In "Proceedings of the London Conference on the Scientific Study of Mental Retardation" (1960). In press.

- Goodwin, H., and Curzon, G. (1959) J. Neurochem., 4, 234.

Diezel, P. B. (1954a) Disch. Z. Nervenheilk., 171, 344.

_- (1954b) Virchows Arch., 326, 89.

(1957) In van Bogaert's "Cerebral Lipidoses." Oxford, p. 52.

(1960) In Cumings' “Modern Scientific Aspects of Neurology.” London, p. 98.

Diezel, P. B., and Richardson, E. P., Jr. (1957) J. Neuropath., 16, 130.

EdGar, G. W. F. (1955a) Excerpta Med., Amst. (sect. 8), 8, 801.

— (19556) Rev. neurol., 92, 277.

(1956) Folia psychiat. neerl., 59, 33.

(1957) In van Bogaert's "Cerebral Lipidoses." Oxford, p. 186. 
Einarson, L. (1951) Acta Psychiat., Kbh., Supp. 74, 180.

(1954) Anatomiske Skr. 1.

-, and Neel, A. V. (1938) Acta Jutlandica, 10, 2.

Favarger, P., and Wildi, E. (1957) In van Bogaert's "Cerebral Lipidoses," Oxford, p. 146.

Feigin, I. (1954) Amer.J. Path., 30, 715.

Folch, J., Lees, M., and Sloane Stanley, G. H. (1957a) J. biol. Chem., $226,497$.

- _- (1957b) In Richter's "Metabolism of the Nervous System." London, p. 174.

Greenfield, J. G. (1933) Proc. R. Soc. Med., 26, 690.

(1950) Folia psychiat. neerl., 53, 255.

Hagberg, B., Sourander, P., Svennerholm, L., and Voss, H. (1960) Acta paediat. Uppsala, 49, 135.

HaIN, R. F., and LAVECK, G. D. (1958) Pediatrics, 22, 1064.

Hirsch, T. V., and Peiffer, J. (1955) Arch. Psychiat. Nervenkr., 194, 88.

- - (1957) In van Bogaert's "Cerebral Lipidoses." Oxford, p. 68.

JATZKeWrTZ, H. (1958) Hoppe-Seyl. Z., 311, 279.

- (1960) Hoppe-Seyl.Z., 318, 265.

Jefferson, M. (1958) Proc. R. Soc. Med., 51, 160.

JerVIS, G. A. (1958) J. Neuropath., 17, 522.

(1960) J. Neuropath., 19, 323.

KLenK, E. (1954) Acta neurol. belg., 54, 586.

LesLie, D. A. (1952) J. Path. Bact., 64, 841.

NoRman, R. M. (1947) Brain, 70, 234.

-_, Urich, H., and Tingey, A. H. (1960) Brain, 83, 369.

OstertaG, B. (1925) Arch. Psychiat. Nervenkr., 75, 355.

Peiffer, J. (1959) Arch. Psychiat. Nervenkr., 199, 386.

- - and Hirsch, T. V. (1955) Excerpta Med., Amst. (sect. 8), 8, 802.

Poser, C. M., Dewulf, A., and VAN Bogaert, L. (1957) J. Neuropath., 16, 209.

Radin, N. S., Lavin, F. B., and Brown, J. R. (1955) J. biol. Chem., 217, 789.

-, Martin, F. B., and Brown, J. R. (1957) J. biol. Chem., 224, 499.

Scholz, W. (1925) Z. ges. Neurol. Psychiat., 99,651.

(1933) Mschr. Psychiat. Neurol., 86, 111.

Seitelberger, F. (1960) In Cumings' "Modern Scientific Aspects of Neurology." London, p. 146.

—, and NAGY, K. (1958) Disch. Z. Nervenheilk., 177, 577.

_-, Vogel, G., and StePan, H. (1957) Arch. Psychiat. Nervenkr., 196, 154.

Svennerholm, L. (1957) In van Bogaert's "Cerebral Lipidoses." Oxford, p. 139.

TingeY, A. (1959) J. Neurochem., 3, 230.

WiCKe, R. (1938) Z. ges. Neurol. Psychiat., 162, 741.

Wislocki, G. B., and Singer, N. (1950) J. comp. Neurol., $92,71$.

WitTe, F. (1921) Münch. Med. Wschr., 68, 69.

Wohlwil., F. J., and Paine, R. S. (1958) Neurology, 8, 285. 


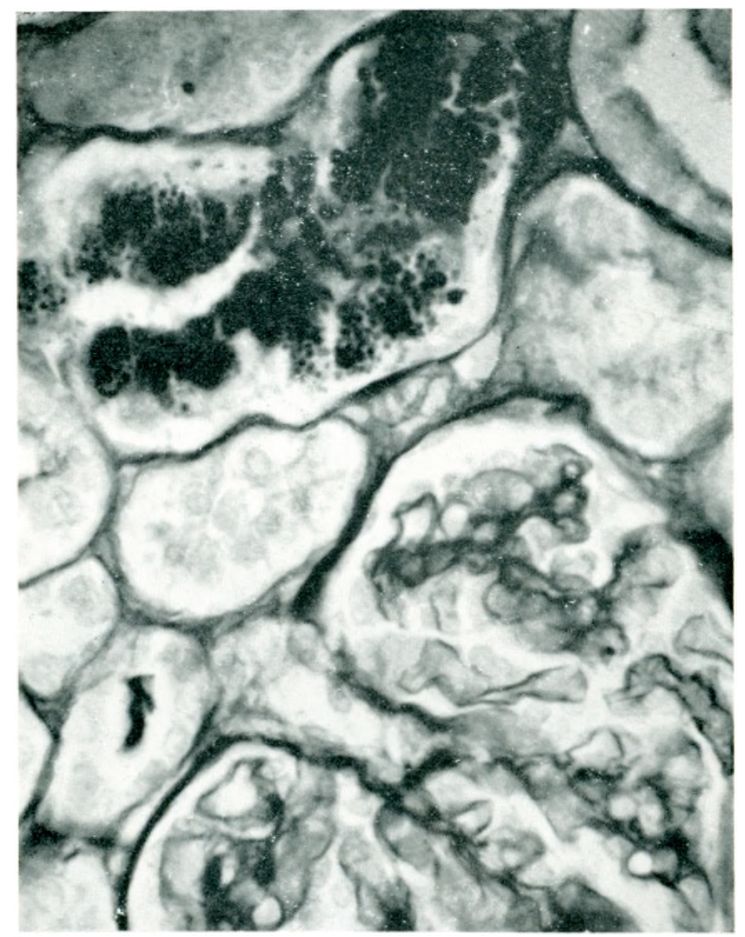

Fig. 2 (Case 2).-Kidney showing PAS positive granules in convoluted tubule. Paraltin. Periodic acid Schiff. $\times 550$.

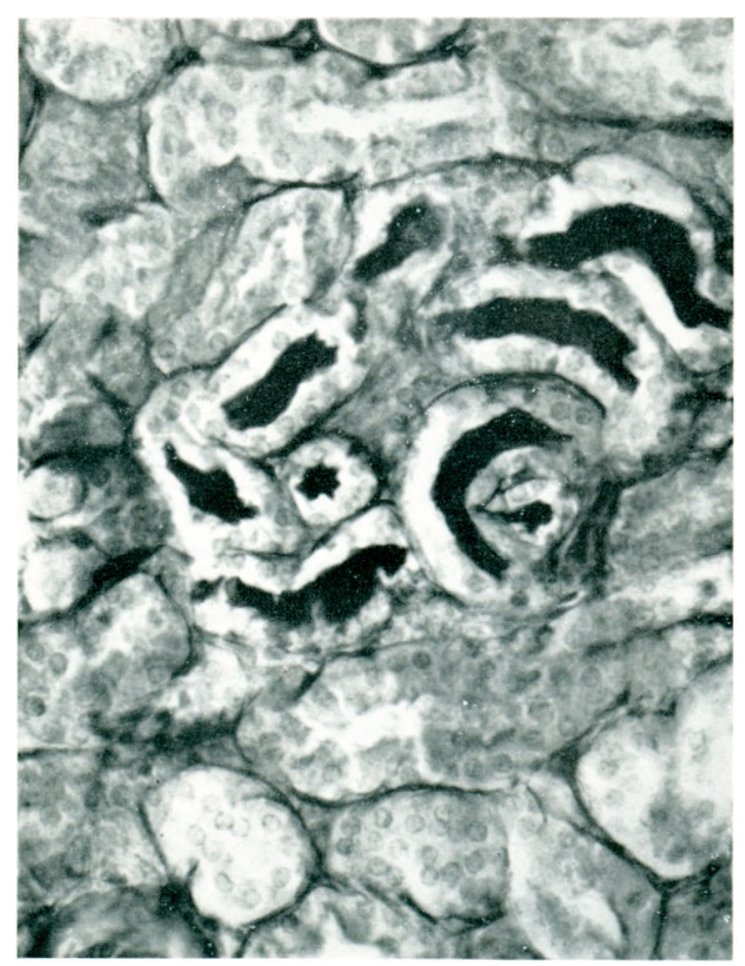

FIG. 3 (Case 2).-Kidney showing PAS positive casts in tubules. Palraffin. Periodic acid Schill. 350.

To illustrate article by Miroslaw Mossakowski, Gordon Mathicson and John N. Cumings. 


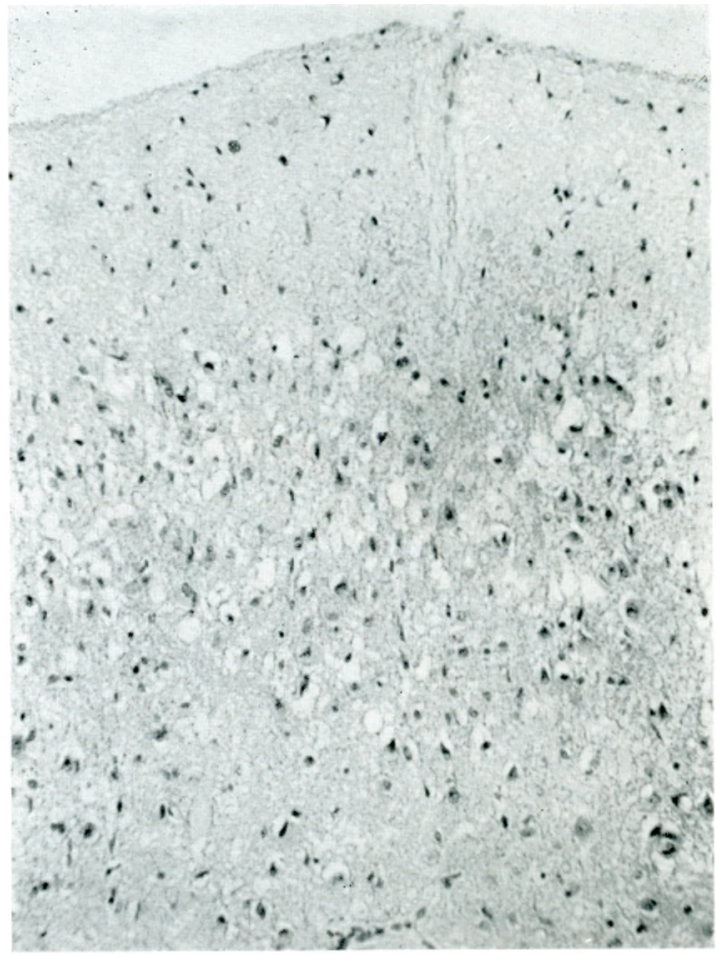

Fig. 4 (Case' 2),-Frontal cortex showing neuronal loss and status spongiosus. Paralfin. Hæmatoxylin and eosin. $\times 130$.

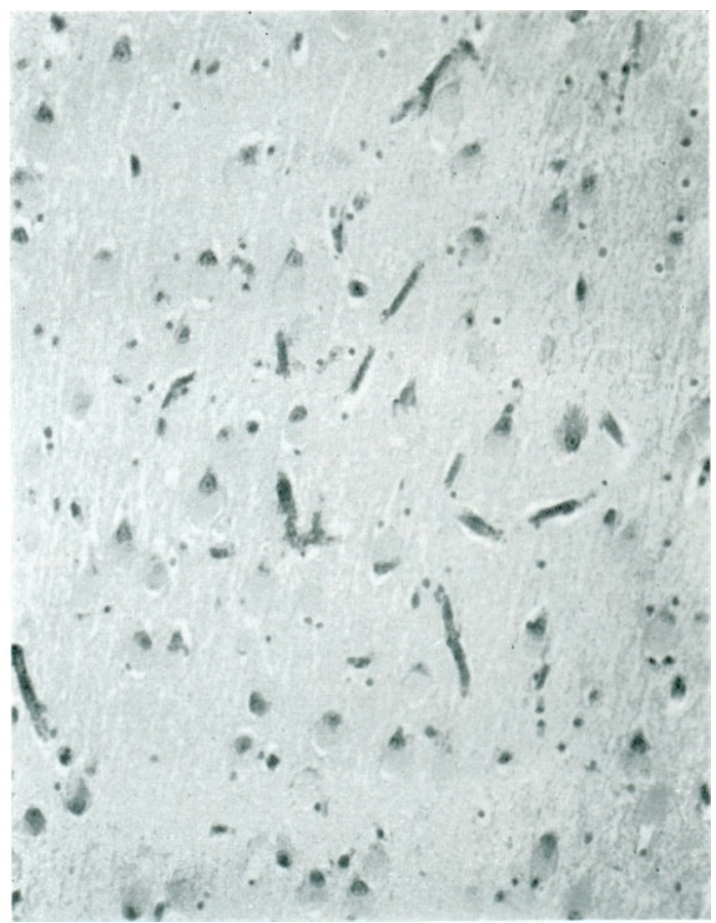

Fig. 5(Case 2), - Hippocampal cortex showing universal distension of nerve cell bodies. Paraffin. Hamaloxylin and eosin. $<250$.

To illustrate article by Miroslaw Mossakowski, Gordon Marhieson and Jolm N. Cumnings. 


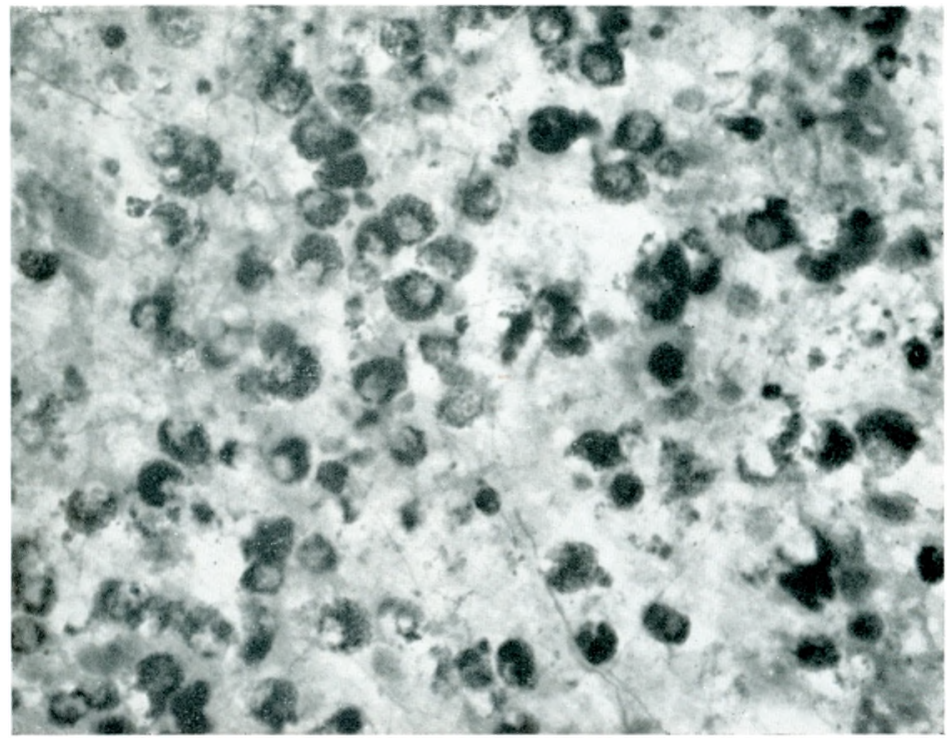

Fici, 6 (Case 2).-Frontal cortex showing abundant lipid accumulation in neuronal cytoplasm. Frozen section. Sudan Black B. $\times 300$.

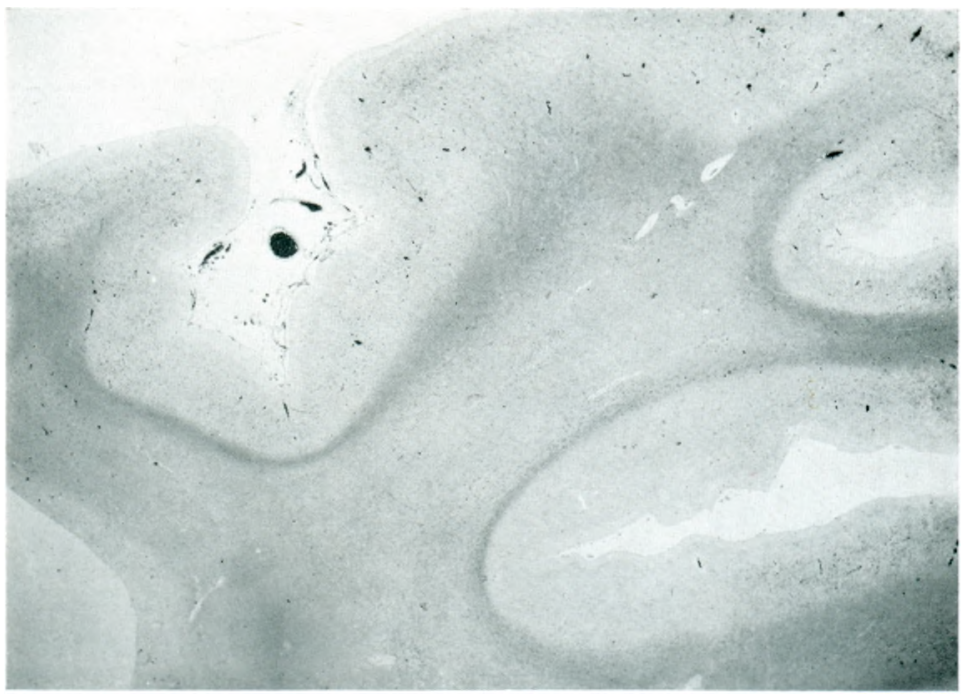

Fig. 7 (Case 2). Frontal lobe. There is widespread demyelination but partial preservation in immediately subcortical regions where, in addition, macrophages contain material with the staining properties of myelin. Paraffin. Heidenhain's method for myelin. $\times 4$. 


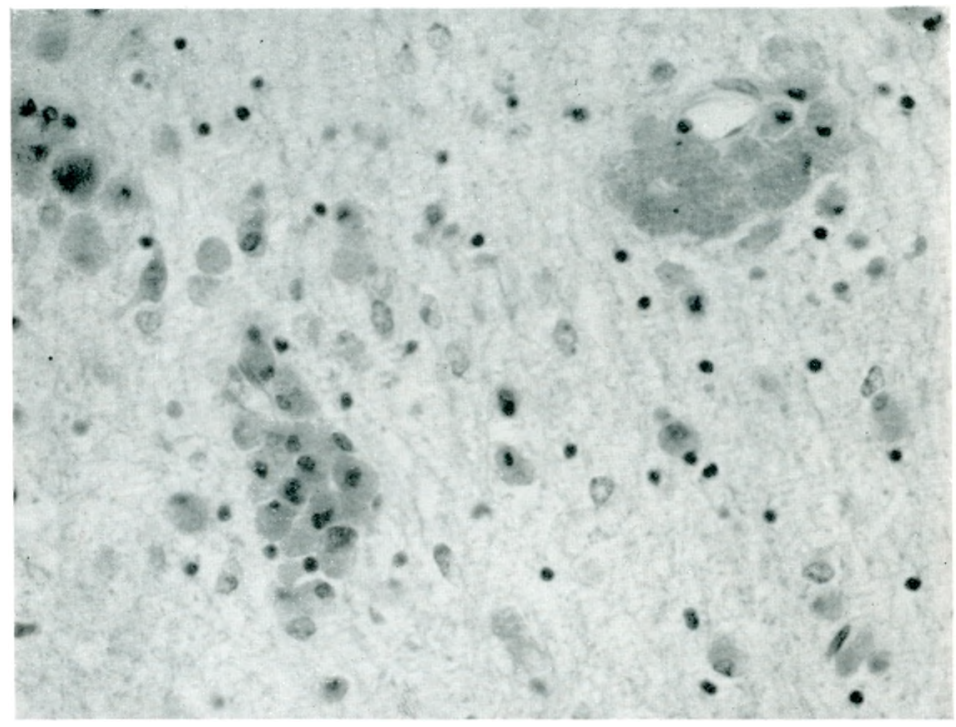

FIG. 8 (Case 2). White matter of centrum ovale showing clusters of macrophages. Paraffin. Hæmatoxylin and eosin. $\times 420$.

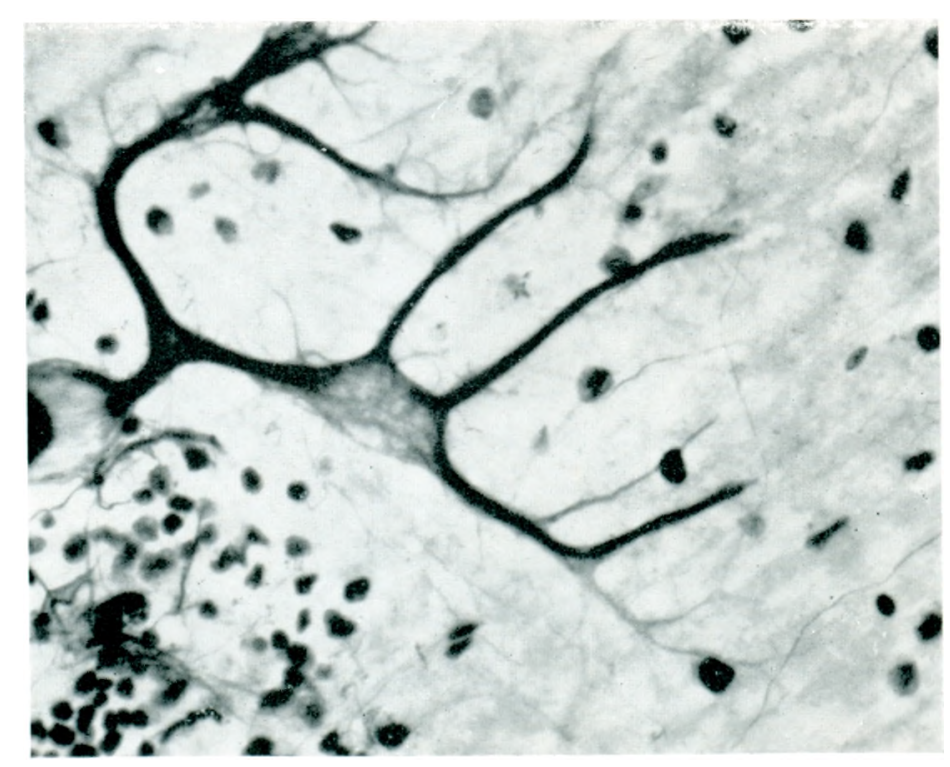

Fig. 9 (Case 2).-Cerebellar cortex. The Purkinje cell body is distended and ovoid. Swellings are present in the dendrites. Frozen section. Bielschowsky's method. $\times 600$. 


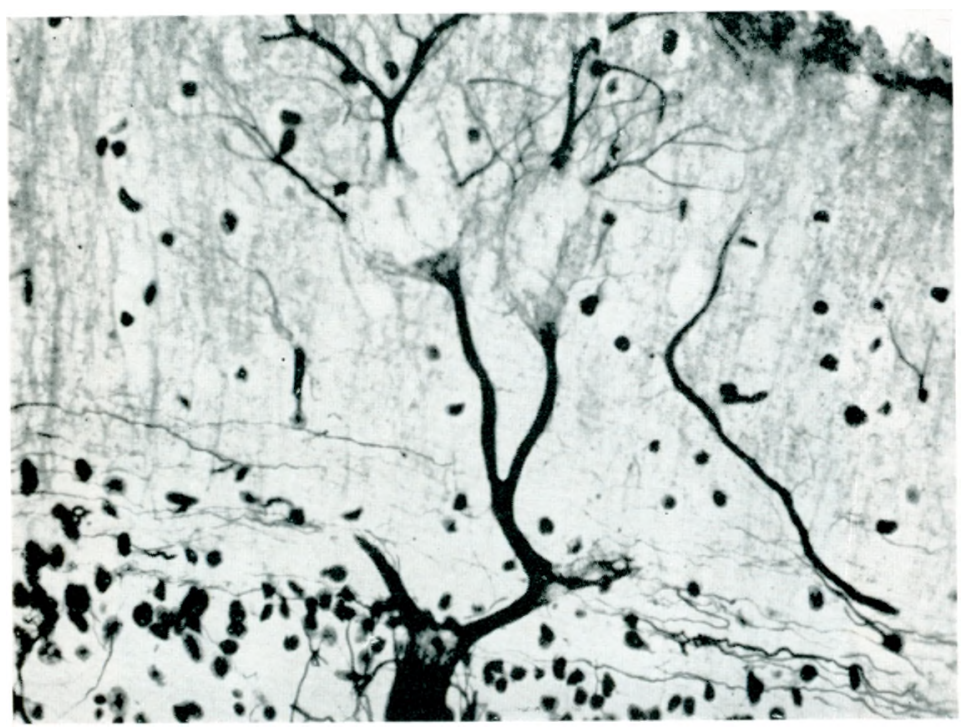

Fig. 10 (Case 2).-Cerebellar cortex. Another Purkinje cell showing ovoid swellings of two of its dendrites. Frozen section. Bielschowsky's method. $\times 600$.

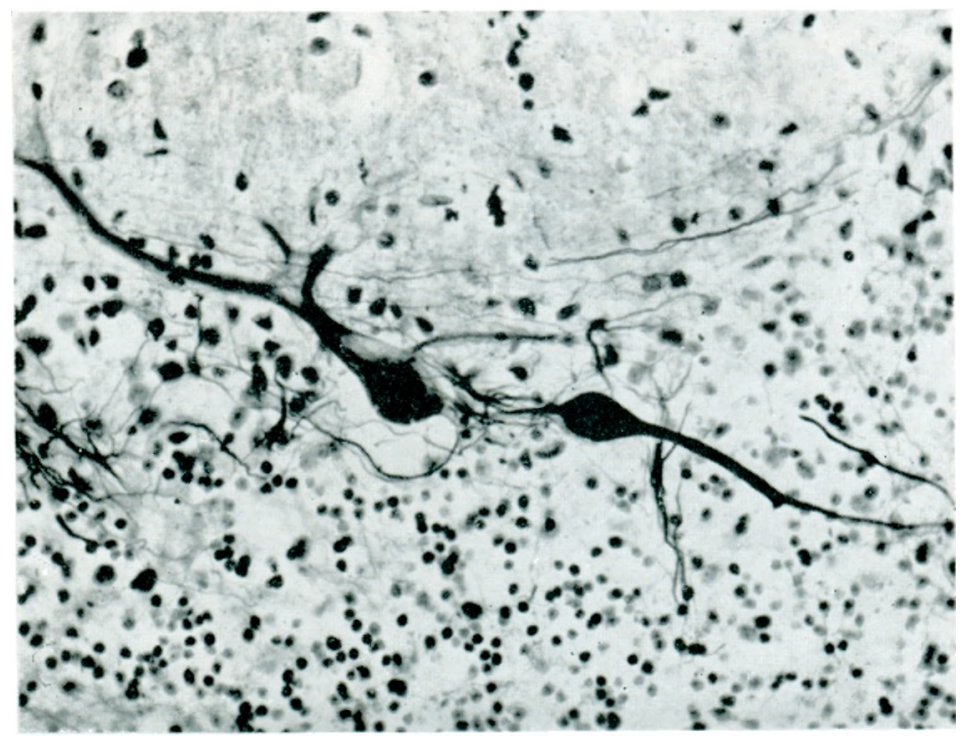

Fig. II (Case 2). Cerebellar cortex showing torpedo-shaped deformity of Purkinje cell axon. Frozen section. Bielschowsky's method. $\times 380$. 


\section{PLATE LXI}

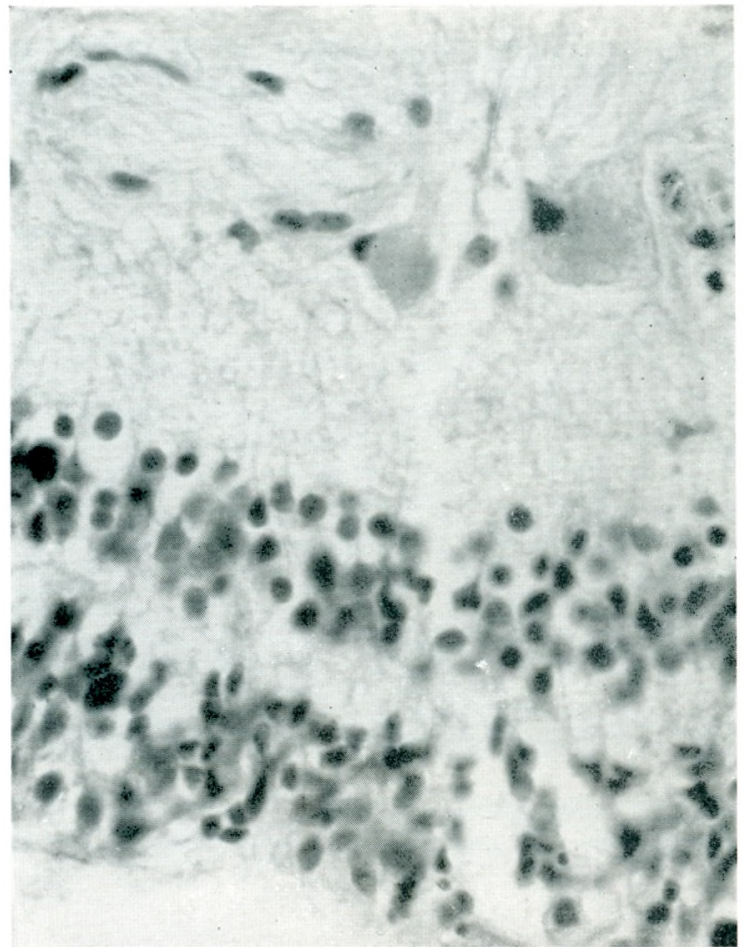

Fig. 12 (Case 2) - Retina. Two distended ganglion cells are scen in the upper part of the picture. The inner and outer nuclear layers are preserved. Paraffin. Hæmatoxylin and eosin. $\times 600$.

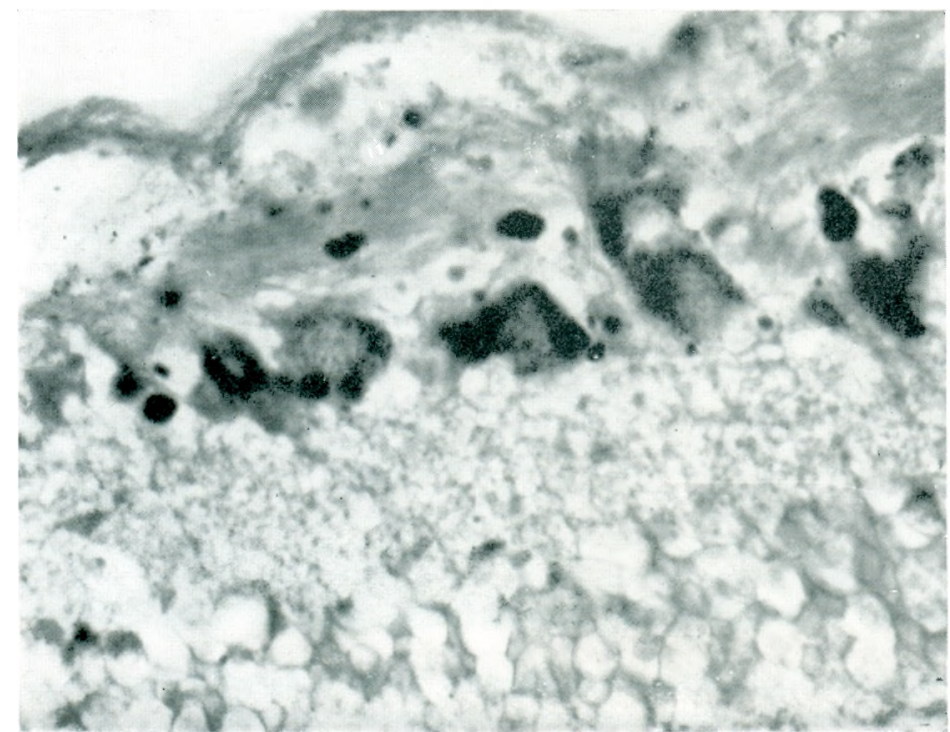

FIG. 13 (Case 2).--Retina showing lipid in ganglion cells. Scaltered lipid granules are also present. Paraffin. Sudan Black B. $\times 520$.

To illustrate article by Miroslaw Mossakowski, Gordon Mathieson and John N. Cumings. 


\section{PLATE LXII}

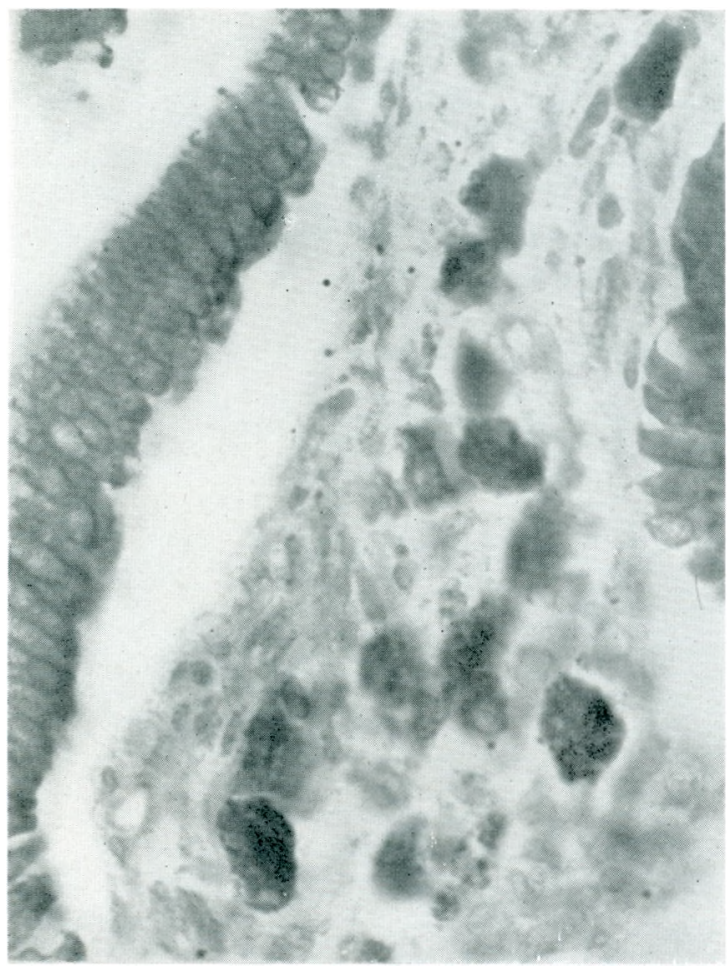

Fig. 14 (Case 3).-Gall-bladder. Lipid-laden macrophages are scattered in the mucosa. Paraffin. Sudan Black B. $\times 520$.

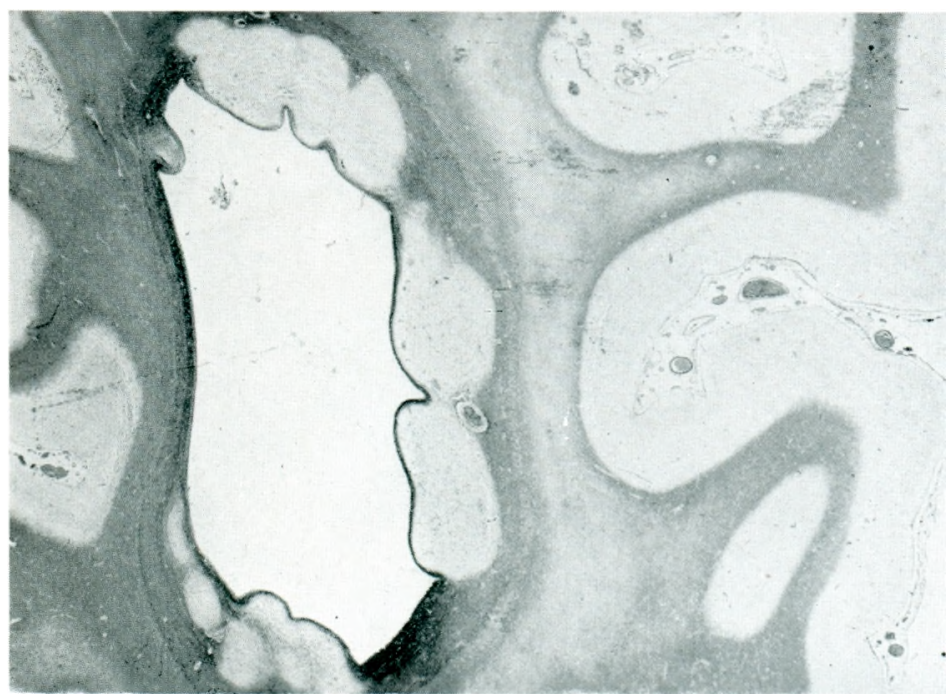

Fig. 15 (Case 3).--Right occipital lobe. The white matter is gliosed. Heterotopic foci of grey matter are present in the ventricular wall. Paraffin. Holzer"s method. $\times 4$.

To illustrate article by Miroslaw Mossakowski, Gordon Mathieson and John N. Cumings. 


\section{PLATE LXIII}

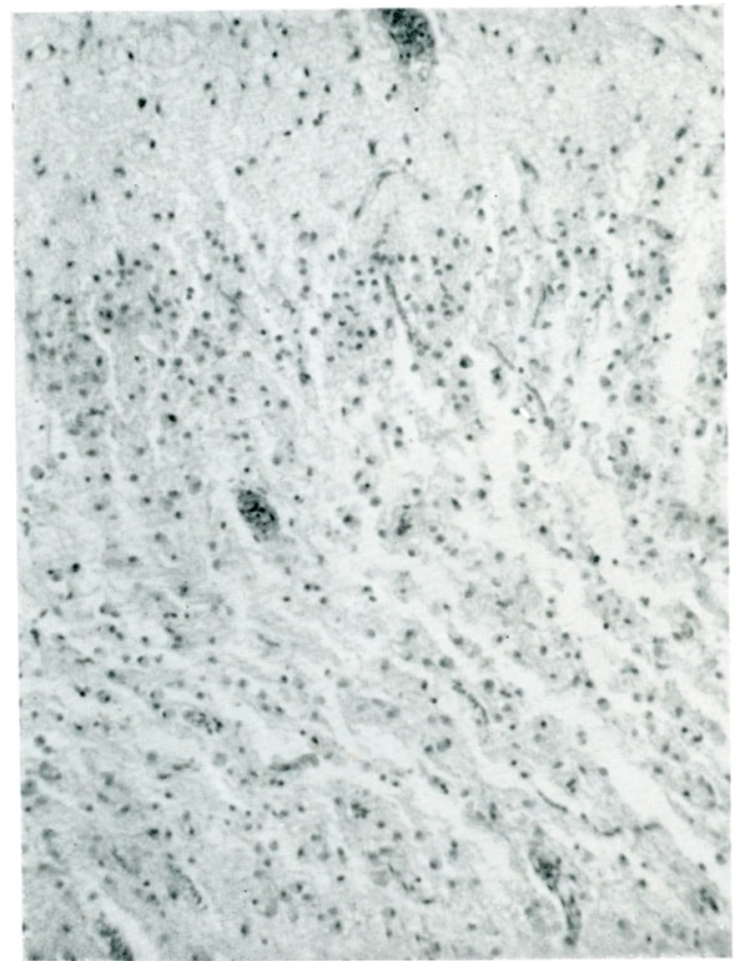

Fig. 16 (Case 3).-Occipital cortex showing destruction of architecture. The molecular layer at the top of the field is spared. Paraffin. Hæmatoxylin and eosin. $\times 130$.

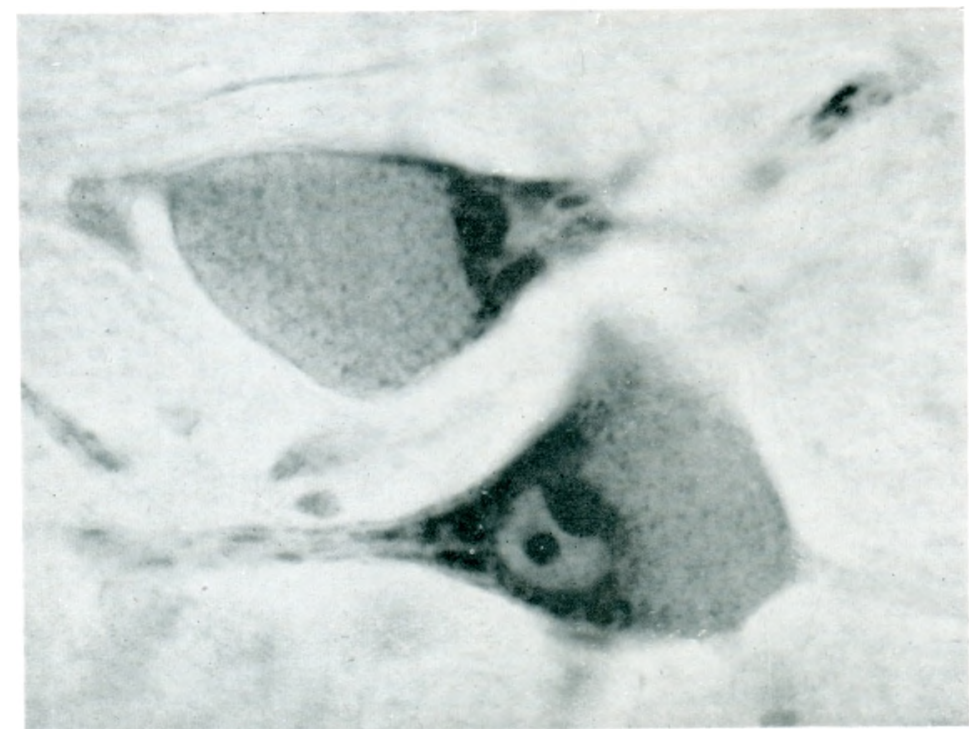

Fig. 17 (Case 3),--Hypoglossal nucleus. Two neurones showing distended, finely granular cytoplasm. The nucleus is displaced and Niss! substance crowded around it. Paraffin. Cresyl violet. $\times \mathbf{7 8 0}$.

To illustrate article by Miroslaw Mossakowski, Gordon Mathieson and John N. Cumings. 


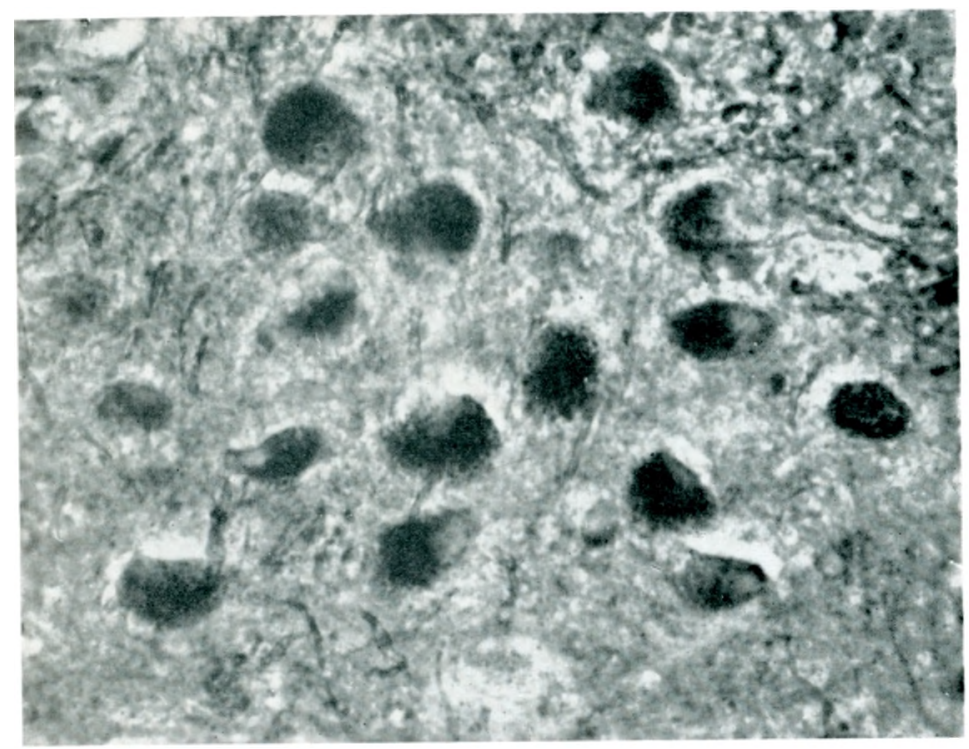

FIG. 18 (Case 3).-Dentate nucleus showing lipid content of neuronal cytoplasm. Frozen section. Sudan Black B. $\times \mathbf{4 0 0}$.

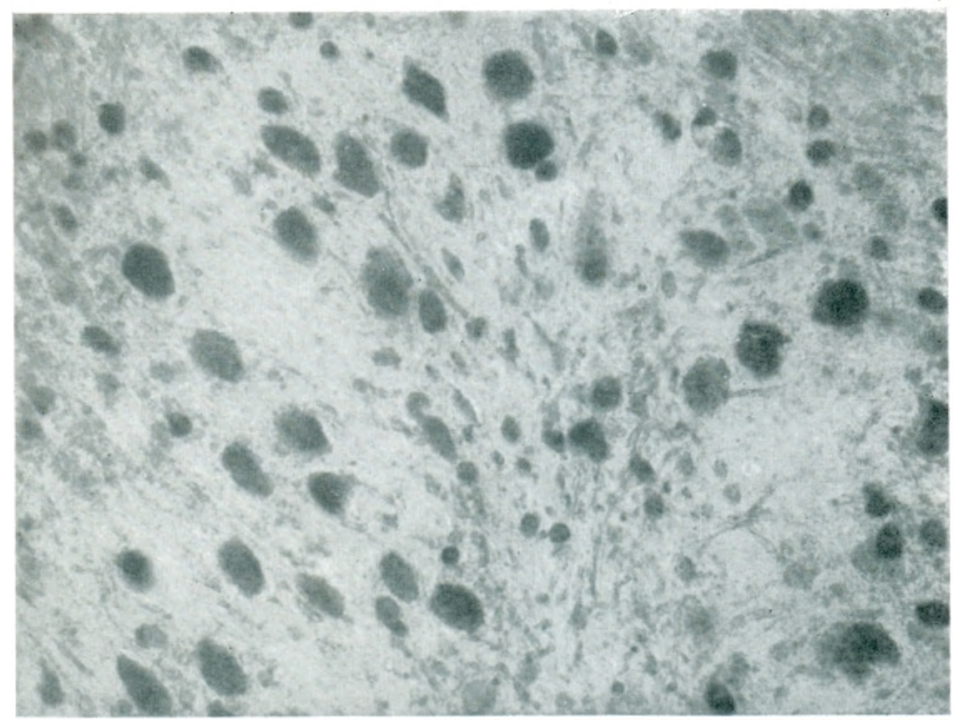

Fig. 19 (Case 2).-Dentate nucleus. Cytoplasmic deposits in the neurones show metachromasia (brown in section). Frozen section. Acetic acid cresyl violet. $\times 190$. 


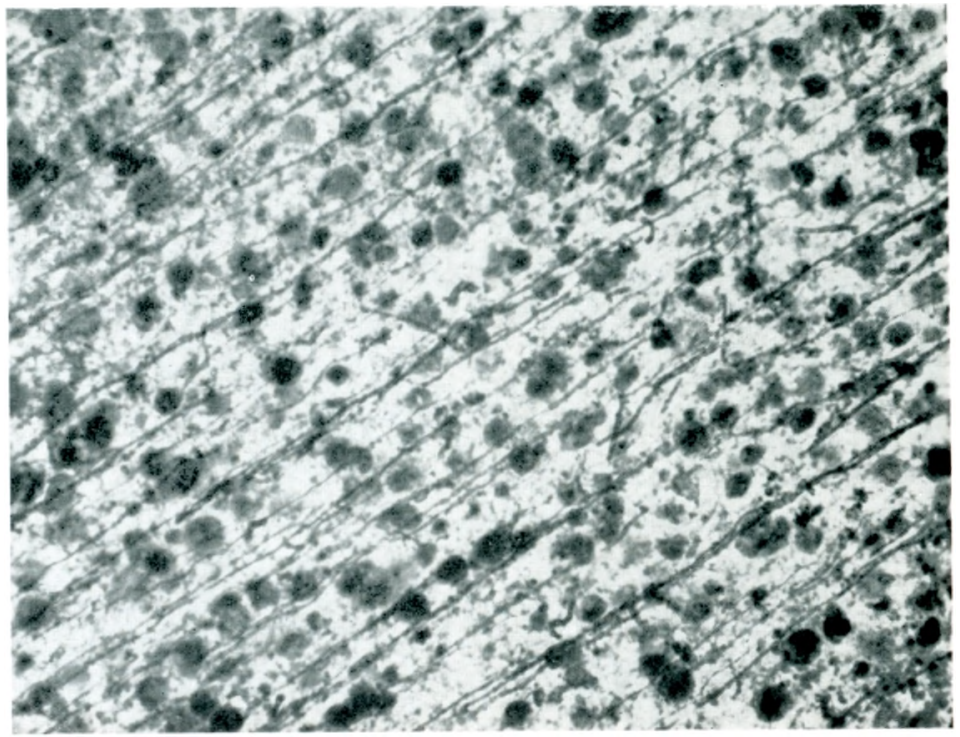

Fici, 20 (Case 2). - White matter of centrum ovale showing residual myelin sheaths and lipid-containing macrophages. Frozen section. Sudan Black B. $\times 160$.

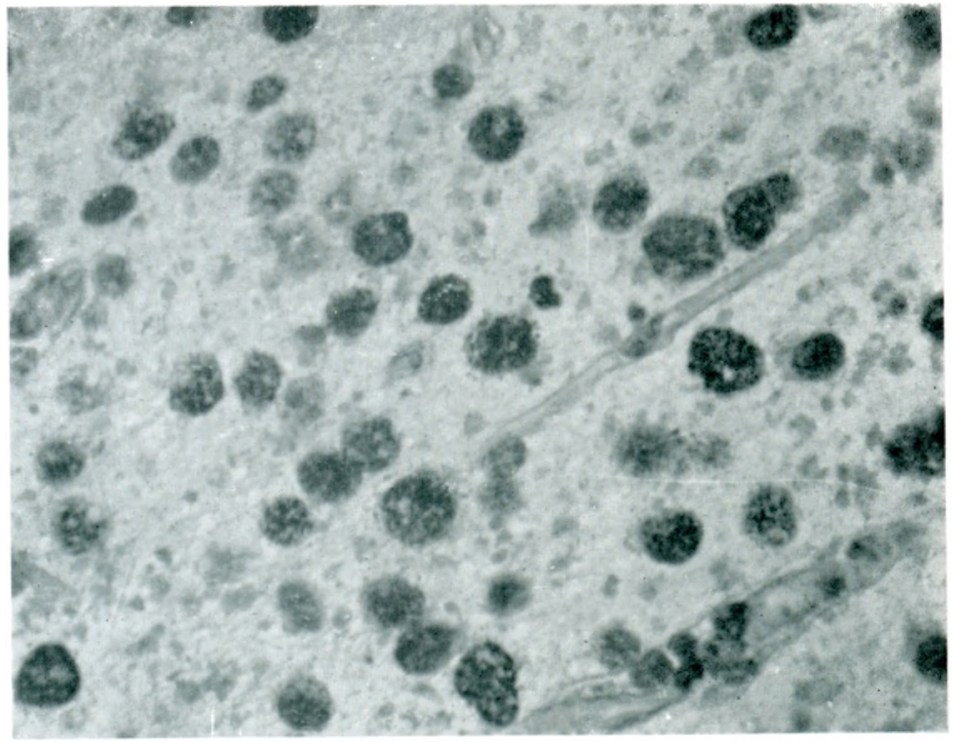

Fici, 2I (Case 3),-White matter of centrum ovale showing macrophages with PAS positive content. Paraffin. Periodic acid Schiff. $\times 300$. 


\section{PLATE LAVI}

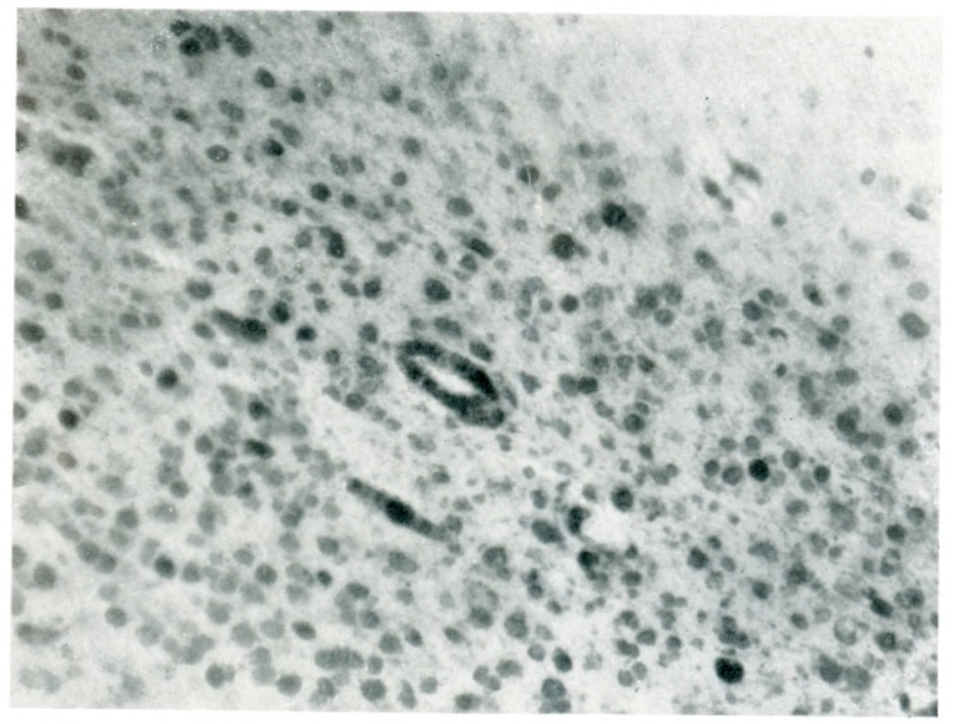

Fic. 22 (Case 2).--Frontal lobe. The white matter contains numerous macrophages with brown metachromatic material. Cerebral cortex at top right is free from metachromatic deposits. Frozen section. Acetic acid cresyl violet. $\times 130$. 
Printed in England

by

STAPLES PRINTERS LIMITED

at their

Great Titchfield Street, London, establishment 